\title{
LATE PALEOZOIC-EARLY MESOZOIC GRANITOIDS IN THE KHANGAY- KHENTEY BASIN, CENTRAL MONGOLIA: IMPLICATION FOR THE TECTONIC EVOLUTION OF THE MONGOL-OKHOTSK OCEAN MARGIN
}

\author{
Ariuntsetseg Ganbat ${ }^{(1,2, *)}$ ariun.0602@gmail.com \\ Tatsuki Tsujimori ${ }^{(1,3)}$ tatsukix@tohoku.ac.jp \\ Laicheng Miao ${ }^{(4)}$ miaolc@mail.iggcas.ac.cn \\ Inna Safonova $^{(5,6)}$ inna03-64@mail.ru \\ Daniel Pastor-Galán ${ }^{(1,3,7)}$ dpastorgalan@gmail.com \\ Chimedtseren Anaad ${ }^{(2,9)}$ chimedtserena@yahoo.com \\ Munkhtsengel Baatar ${ }^{(2,8)}$ tsengel@must.edu.mn \\ Shogo Aoki ${ }^{(10,11)}$ s-aoki@gipc.akita-u.ac.jp \\ Kazumasa Aoki ${ }^{(11)}$ kazumasa@das.ous.ac.jp \\ Ilya Savinskiy ${ }^{(5)} \underline{\text { ilya.savinskiy@gmail.com }}$ \\ ${ }^{(1)}$ Department of Earth Science, Graduate School of Science, Tohoku University, Aoba, Sendai 980-8578, \\ Japan \\ ${ }^{(2)}$ Geoscience Center, Mongolian University of Science and Technology, Ulaanbaatar 120646, Mongolia \\ (3) Center for Northeast Asian Studies, Tohoku University, Aoba, Sendai 980-8576, Japan \\ (4) Institute of Geology and Geophysics, Chinese Academy of Sciences, Beijing 100029, China \\ (5) Novosibirsk State University, Pirogova St. 1, Novosibirsk, 630090, Russia \\ (6) Sobolev Institute of Geology and Mineralogy, SB RAS, Koptyuga ave. 3, Novosibirsk, 630090, Russia

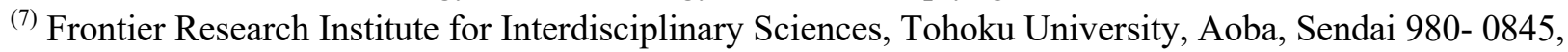 \\ Japan \\ ${ }^{(8)}$ Mongolian University of Science and Technology, Ulaanbaatar 120646, Mongolia \\ ${ }^{(9)}$ Natural History Museum of Mongolia, Ulaanbaatar, 120646, Mongolia \\ ${ }^{(10)}$ Graduate School of International Resource Sciences, Akita University, Akita 010-8502, Japan \\ ${ }^{(11)}$ Center for Fundamental Education, Okayama University of Science, Okayama 700-0005, Japan
}

This Manuscript has been submitted for publication in LITHOS in April, 2021. Please note that despite having undergone peer-review, the manuscript has not been formally accepted yet for publication and, therefore, it may be subject to some changes. Subsequent versions of the manuscript may include slightly different content. If accepted the final version of the manuscript will be available through the "PEER REVIEW PUBLICATION DOI" link. 
Late Paleozoic-Early Mesozoic granitoids in the Khangay-Khentey basin, Central Mongolia: Implication for the tectonic evolution of the Mongol-Okhotsk Ocean margin

Ariuntsetseg Ganbat ${ }^{\left(1,2,{ }^{*}\right)}$ https://orcid.org/ 0000-0003-2464-4161

Tatsuki Tsujimori ${ }^{(1,3)}$ https://orcid.org/0000-0001-9202-7312

Laicheng Miao ${ }^{(4)}$ https://orcid.org/ 0000-0001-6296-4444

Inna Safonova ${ }^{(5,6)}$ https://orcid.org/ 0000-0003-2464-4161

Daniel Pastor-Galán ${ }^{(1,3,7)}$ https://orcid.org/ 0000-0002-0226-2739

Chimedtseren Anaad ${ }^{(2,9)}$ https://orcid.org/ 0000-0001-7878-0738

Munkhtsengel Baatar ${ }^{(2,8)}$ https://orcid.org/ 0000-0002-9644-3599

Shogo Aoki ${ }^{(10,11)}$ https://orcid.org/ 0000-0001-5093-1346

Kazumasa Aoki ${ }^{(11)}$ https://orcid.org/ 0000-0001-7645-6766

Ilya Savinskiy ${ }^{(5)}$ https://orcid.org/ 0000-0001-9430-9794

(1) Department of Earth Science, Graduate School of Science, Tohoku University, Aoba, Sendai 980-8578, Japan

(2) Geoscience Center, Mongolian University of Science and Technology, Ulaanbaatar 120646, Mongolia

(3) Center for Northeast Asian Studies, Tohoku University, Aoba, Sendai 980-8576, Japan

(4) Institute of Geology and Geophysics, Chinese Academy of Sciences, Beijing 100029, China

(5) Novosibirsk State University, Pirogova St. 1, Novosibirsk, 630090, Russia

(6) Sobolev Institute of Geology and Mineralogy, SB RAS, Koptyuga ave. 3, Novosibirsk, 630090, Russia

(7) Frontier Research Institute for Interdisciplinary Sciences, Tohoku University, Aoba, Sendai 9800845, Japan

(8) Mongolian University of Science and Technology, Ulaanbaatar 120646, Mongolia

(9) Natural History Museum of Mongolia, Ulaanbaatar, 120646, Mongolia

(10) Graduate School of International Resource Sciences, Akita University, Akita 010-8502, Japan

(11) Center for Fundamental Education, Okayama University of Science, Okayama 700-0005, Japan 


\section{Introduction}

The continental crust of the Earth is unique by the presence of granites, compared to other planets of the solar system. Its origin and evolution have been a matter of debate among Earth scientists for a long time (Taylor and McLennan, 1995; Chen and Grapes, 2007). Granites are essential for deciphering crustal growth and tectonic evolution of the Earth and for assessing related mineral deposits (e.g., Clemens et al., 2020). Granites and their associated volcano-plutonic suites can provide critical information about orogeny-related igneous petrogenesis and geodynamic framework. Petrogenetic and tectonic reconstructions require zircon $\mathrm{U}-\mathrm{Pb}$ age dating and up-to-date geochemical and isotopic studies (e.g., Pearce and Peate, 1995; Kemp et al., 2006). The Central Asian Orogenic Belt (Fig. 1a; CAOB or Altaids) is the world largest accretionary orogenic belt separating the Siberian, Kazakhstan, Tarim, and North China continental blocks and is the site of the most significant Phanerozoic juvenile crustal growth on Earth (e.g., Jahn et al., 2004; Windley et al., 2007; Xiao et al., 2010; Safonova et al., 2011, 2017; Kröner et al., 2014). Evidence for the dominantly juvenile character of the $\mathrm{CAOB}$ crust comes from low whole-rock initial $\mathrm{Sr}$ and high $\mathrm{Nd}$ and high Hf-in-zircon isotopic values of the CAOB igneous rocks and from the Pacific-type nature of the CAOB constituting local orogenic belts (e.g., Jahn et al., 2004; Safonova et al., 2011, 2017; Wilhem et al., 2012). However, the proportions of juvenile and recycled crust in the CAOB, hosting numerous volcano-plutonic complexes/suites (Fig. 1b), are still a matter of debates as many formations still lack up-to-date analytical data and many areas lack reliable tectonic models (e.g., Jahn et al., 2004; Kröner et al., 2014; Safonova, 2017). The solution to these problems requires reconstructing tectonic frameworks in different segments of the CAOB.

The CAOB was formed by the evolution and suturing of the Paleo-Asian Ocean and its related oceanic realms or branches, e.g., Turkestan or South Tienshan Ocean in the west and Mongol-Okhotsk Ocean (MOO) in the east. The closure of the MOO by the approaching Siberian and Central Mongolia-Erguna block in the Late Paleozoic-Mesozoic time led to the formation of the Mongol-Okhotsk Belt (MOB) in the northeastern CAOB (e.g., Donskaya et al., 2013; Yi and Meert, 2020). The MOB hosting numerous volcano-plutonic series is the youngest and one of the most critical segments of the CAOB and hosts numerous volcano-plutonic series (Fig. 1b). Despite the extensive research during the last three decades, whether these volcano-plutonic series are related to the evolution of the MOO is still an issue of hot debate. One viewpoint is that they have been formed in a within plate setting without any link with the MOO (Yarmolyuk et al., 2002). An alternative model is that they were related to the subduction of MOO. Another uncertainty is whether this ocean closed with bi-directional subduction (Tomurtogoo et al., 2005) or whether there was subduction along the northern margin beneath the Siberian craton (e.g., Munkhtsengel et al., 2007; Donskaya et al., 2013), or southern margin beneath the Central Mongolia-Erguna Block 
which is also referred to as Amur or Amurian Superterrane (e.g., Zhu et al., 2016; Zhao et al., 2017; Sorokin et al., 2020).

It needs to point out that previous studies of the MOB were mostly within the territories of China (e.g., Sun et al., 2013; Liu et al., 2018) and Russia (e.g., Izbrodin et al., 2020). The amount of up-to-date geochronological and geochemical data from granitic plutons and volcano-plutonic belts in the Mongolian part of the belt remains limited to solve confidently the problem of their origin and subduction evolution of the MOO. In this paper, we present U-Pb zircon ages, major and trace element geochemical data, whole-rock $\mathrm{Nd}$ and in-situ zircon $\mathrm{Hf}$ isotopic compositions for the granitic plutons hosted by the Khangay and Khentey Batholiths (Figs. 1b, 1c), in an attempt to constrain the formation time of the granitic plutons or the volcano-plutonic series, to understand their petrogenesis, and to reconstruct geodynamic settings of their formation. The new results will shed light on the Late Paleozoic-Early Mesozoic evolution of the MOB, as well as the nature of continental crust growth in the eastern CAOB.

\section{Regional and local geology}

The territory of Mongolia occupies a central position within the CAOB (Fig. 1b), and has been subdivided into two tectonic domains by the Main Mongolian Lineament (MML), to the northern and the southern (Badarch et al., 2002; Tomurtogoo et al., 2005). The northern domain comprises cratonic fragments, Neoproterozoic ophiolites, Precambrian and Early Paleozoic metamorphic rocks, and Early Paleozoic basins with clastic rock, island arcs, and associated volcanoclastic sediments (Badarch et al., 2002). The southern domain consists of Paleozoic island arcs, ophiolite fragments, and Late Carboniferous to Permian volcanic rocks (Wilhem et al., 2012). These two domains are bounded by Khangay-Khentey basin, part of the Mongol-Okhotsk Belt.

The Mongol-Okhotsk Belt extends over a distance of more than 3,000 km from Central Mongolia to the Uda Bay in the Okhotsk Sea over the territories of Mongolia, Russia, and NE China (Fig. 1b). The Silurian to Carboniferous oceanic sedimentary sequences of the KhangayKhentey basin (part of the Mongol-Okhotsk Belt) are overlain by Triassic terrigenous continental deposits. The Khangay-Khentey basin also includes the Adaatsag and Khuhu Davaa ophiolites with crystallization ages from 314 to $325 \mathrm{Ma}$, and associated accretionary complexes (Tomurtogoo et al., 2005; Zhu et al., 2018) marking the suture zone of the MOO (Fig. 2). The accretionary complexes include oceanic basalt (mostly OIB-type), Silurian-Devonian radiolarian pelagic chert, hemipelagic siliceous mudstone and siltstone, and trench turbidite, all elements of Ocean Plate Stratigraphy (OPS), and fore-arc greywacke sandstone (e.g., Dagva-Ochir et al., 2020). The U-Pb ages of detrital zircons show that the sedimentary records of the Khangay-Khentey basin were started after Early 
Carboniferous time (Badarch et al., 2002; Bussien et al., 2011). The general geology and the numerous intrusions of mafic to felsic igneous rocks younging from west to east along the MongolOkhotsk suture (Donskaya et al., 2013), suggest that the ocean closed in a scissor-like manner during a period from the late Carboniferous to the Permian in central Mongolia and/or until the Triassic-Early Jurassic or Cretaceous in southeastern Transbaikalia and NE China, but the accurate time of its closure remains debatable (e.g., Sorokin et al., 2020). The subduction of the MOO can be responsible for the paired volcano-plutonic belts that once existed around the suture, hosting abundant granitoid intrusions: plutons with various sizes and huge batholiths. Among those are Angara-Vitim, Erguna, Khangay, and Khentey Batholiths (Fig. 1b). The Angara-Vitim batholith developed on the heterogeneous basement as its granitoids yielded U-Pb ages ranging from 278 to $333 \mathrm{Ma}$ (e.g., Izbrodin et al., 2020). The Erguna batholith formed in an arc and back-arc settings in Carboniferous time (e.g., Sun et al., 2013), and continued until Early-Middle Jurassic (Liu et al., 2018). The Khangay Batholith is located in the western Mongol-Okhotsk Belt (Fig. 1c). It consists of several plutonic complexes formed in two stages. The earlier intrusion of granodiorite, tonalite, plagiogranite, and gabbro-diorite was followed by the intrusion of diverse granitoids, such as hornblende biotite granite, biotite-tonalite, granodiorite, and alkaline granite. The available U-Pb zircon, $\mathrm{Rb}$-Sr isochron, and $\mathrm{Ar} / \mathrm{Ar}$ ages from the Khangay batholith range from 237 to $263 \mathrm{Ma}$ (Jahn et al., 2004). The Khentey batholith is dominated by granodiorite and leucogranite with subordinate gabbro and diorite. The U-Pb zircon ages and $\mathrm{Rb}-\mathrm{Sr}$ isochron ages obtained from Khentey granitoids range from 186 to $226 \mathrm{Ma}$ (Yarmolyuk et al., 2002). To the south, the Khentey batholith is bordered by abundant coeval series of bimodal volcanic rocks and alkaline Li-F granites (e.g., Yarmolyuk et al., 2002).

Of special interest is the Selenge volcano-plutonic Belt located in the northern MOB (Fig. 1c) as it hosts the world-famous Erdenet copper-porphyry deposit. The Selenge Pluton which is closely related to the mineralization is a composite intrusion. The oldest Selenge Pluton (253-277 Ma) consists of calc-alkaline shoshonite-latite rocks, and coeval volcanics (Munkhtsengel et al., 2007). The younger $240 \mathrm{Ma}$ quartz-diorite yielded $\varepsilon_{\mathrm{Hf}}(t)$ values from +6.9 to +14.8 and $\mathrm{T}_{\mathrm{DM} 2}(\mathrm{Hf})$ ages between 320 and 830 Ma. The Triassic magmatic activity formed alkaline intrusions and bimodal igneous series different from older subduction-related magmas (Morozumi et al., 2003). The ore-bearing Erdenet intrusions yielded an age of 235-245 Ma and molybdenite yielded a ReOs age of $240 \mathrm{Ma}$ (Morozumi et al., 2003).

The study area is located in the southern margin of the Khangay-Khentey basin, northwest of the Mongol-Okhotsk suture near the Delgerkhaan town (Fig. 2). It hosts several granitoid plutons, including undifferentiated bodies and namely Batkhaan, Zambalkhudag, Delgerkhaan plutons, which are foci of this paper. They are compositionally caries from diorite, granodiorite, 
minor monzogranite to alkaline granite (Tumurchudur et al., 2006). The Batkhaan granitoid pluton of Permian age consists of subalkaline granite, syenogranite, quartz syenite, quartz diorite, associated with trachyrhyolite, rhyolite, and dacite. This association is overlain by Late Permian conglomerate, silicified sandstone, and siltstone strata with fauna and flora. The Delgerkhaan granitoid pluton occupies a large area and consists of calc-alkaline biotite-hornblende granite, granodiorite, monzodiorite, monzogabbro carrying mafic xenoliths (Tumurchudur et al., 2006; Amar-Amgalan, 2008). The Delgerkhaan granitoids are cut by numerous NE-trending 1-3 m wide mafic to intermediate dykes. Near the granitoid body, there are outcrops of mafic to felsic volcanic rocks. Biotite from trachyandesite yielded a K-Ar age of $223 \mathrm{Ma}$ (Tumurchudur et al., 2006). According to the 1:200 000 scale State Geological Map (Dagvadorj et al., 1993), the Zambalkhudag pluton consists of Late Carboniferous calc-alkaline biotite- granite, granodiorite, and leucogranite. An undifferentiated smaller body, previously assumed as Cambrian granite-granodiorite, is overlain by felsic volcanogenic formations, which lithostratigraphic age is accepted as Early Permian (Fig. 2) (Dagvadorj et al., 1993). The igneous rocks intrude Devonian-Carboniferous dark gray sandstone, polymictic sandstone, conglomerate, gravel, and chert. In addition, there are Late Triassic syenite, diorite, monzodiorite, and mafic to intermediate volcanic rocks and Cretaceous basaltic andesite all covered by oil-bearing shale-siltstone-sandstone strata (Tumurchudur et al., 2006).

\section{Analytical methods}

\subsection{Zircon U-Pb geochronology}

Zircon crystals were separated in Tohoku University, using standard techniques including conventional rock-crushing, magnetic and heavy liquid separation, and handpicking under a binocular microscope. Then, zircon crystals were mounted in epoxy discs. Zonation of zircon interiors was documented using cathodoluminescence (CL) imaging using a Hitachi S-3400N scanning electron microscope, equipped with a Gatan MiniCL. In-situ zircon U-Pb dating was carried out in the Okayama University of Science by using a Thermo Fisher Scientific iCAP-RQ single-collector quadrupole coupled to a Teledyne Cetac Technologies Analyte G2 ArF excimer laser ablation (LA) system equipped with a HelEx 2 volume sample chamber. The laser ablation was conducted at the laser spot size of $25 \mu \mathrm{m}$, the fluence of $1.8 \mathrm{~J} / \mathrm{cm}^{2}$, and the repetition rate of 5 $\mathrm{Hz}$ (for details see Aoki et al., 2020). Zircon standard 91500 (1065 Ma; Wiedenbeck et al., 2004) was used for age calibration, NIST SRM 612 standard (Jochum et al., 2011) for instrument optimization, and Plešovice zircons (337 Ma; Sláma et al., 2008) as secondary standards for quality control. Zircons from samples D0815 and D0817 were analyzed for U-Pb ages at the Beijing SHRIMP Center, China, with a SHRIMP II, following the standard procedures described in (Jian et 
al., 2012). Prior to each analysis, the rastering of primary beams, was applied to minimize contamination by surface Pb. Standards M257 (561.3 Ma, U = $840 \mu \mathrm{g} / \mathrm{g}$; Nasdala et al., 2008) and TEMORA (417 Ma; Black et al., 2003) were used for the calibration of U concentrations and U-Pb ages, respectively. U-Pb ages and concordia diagrams were calculated and plotted using IsoplotR software (ver. 3.75; Vermeesch, 2018); the concordia age of each sample incorporates errors on decay constants and includes evaluation of the concordance of apparent ages. The concordia ages and errors are presented at the two-sigma level.

\subsection{Whole-rock geochemistry}

Twenty-five samples were selected for whole-rock analysis. Concentrations of major and trace elements were measured at Activation Laboratories Ltd., Canada, using Code 4Litho Lithogeochemistry Package with fusion inductively coupled plasma optical emission spectrometry (FUS-ICPOES) and inductively coupled plasma mass spectroscopy (FUS-ICPMS), respectively. Thirty-one more samples were analyzed at the Key Laboratory of Lithospheric Evolution, Institute of Geology and Geophysics CAS. Major oxides were obtained from X-ray fluorescence (XRF) with the analytical uncertainties ranging between 1-3\%. An Inductively Coupled Plasma Mass Spectrometer (ICP-MS) was used to determine rare earth elements (REE) and trace elements. The measurement error and drift were controlled by regular analysis of standard samples with a periodicity of $10 \%$. The analyzed uncertainties of ICP-MS data at the $\mu \mathrm{g} / \mathrm{g}$ level are better than $3-$ $10 \%$ for the trace elements, and $\sim 5-10 \%$ for the REE procedure at the Institute of Geology and Geophysics, Chinese Academy of Sciences. Procedural blanks were $<100$ pg for Sm and Nd. Five more samples of granitoids were analyzed at the Analytical Center for Multi-Element and Isotope Studies of the Institute of Geology and Mineralogy, Novosibirsk, Russia. Major oxides were determined by the X-ray fluorescence (XRF) method using an Applied Research Laboratories ARL9900-XP analyzer, following the standard procedure. Trace elements were analyzed by mass spectrometry with inductively coupled plasma (ICP-MS) after fusion with $\mathrm{LiBO}_{2}$. Simultaneous determination of all elements was carried out to low, medium, and high resolution, on a Finnigan Element-II high-resolution mass spectrometer with external calibration using BHVO-1 reference samples and an internal standard. The method has been validated through the analysis of nine reference materials. Relative standard deviations for all elements were $<10 \%$ within the determined concentration ranges.

\subsection{Hf-in-zircon isotopes}

Hf isotope analyses were carried out using a Neptune Plus MC-ICP-MS (Thermo Fisher Scientific, Germany) in combination with a Geolas 2005 excimer ArF laser ablation system (193 
$\mathrm{nm})$ at the Institute of Geology and Geophysics, Chinese Academy of Science, Beijing. The analyses for zircon grains from the granites were conducted with a beam diameter of $63 \mu \mathrm{m}, 6 \mathrm{~Hz}$ repetition rate, and energy of $15 \mathrm{~mJ} / \mathrm{cm}^{2}$. This setting yielded a signal intensity of $10 \mathrm{~V}$ at $180 \mathrm{Hf}$ for the standard zircon 91500. Typical ablation time was $26 \mathrm{~s}$, resulting in pits 20-30 $\mu \mathrm{m}$ deep. The initial ${ }^{176} \mathrm{Hf} /{ }^{177} \mathrm{Hf}$ ratios for the unknown samples were calculated to their initial value, using the measured ${ }^{176} \mathrm{Lu} /{ }^{177} \mathrm{Hf}$ ratios, the apparent age of each zircon grain, and a ${ }^{176} \mathrm{Lu}$ decay constant of $1.867 \times 10^{-11} \mathrm{yr}^{-1}$ (Söderlund et al., 2004). The calculations of epsilon Hf were done using a present-day chondritic ${ }^{176} \mathrm{Hf} /{ }^{177} \mathrm{Hf}$ value of 0.282785 and ${ }^{176} \mathrm{Lu} /{ }^{177} \mathrm{Hf}$ of 0.0336 (Bouvier et al., 2008) and the present-day felsic crustal ratio of ${ }^{176} \mathrm{Lu} /{ }^{177} \mathrm{Hf}=0.015$.

\subsection{Sm-Nd isotopic analysis}

Sm-Nd isotopic analyses were performed at the Institute of Geology and Geochronology, Russian Academy of Sciences, Saint-Petersburg. About $100 \mathrm{mg}$ of whole-rock powder was dissolved in a mixture of $\mathrm{HF}, \mathrm{HNO}_{3}$, and $\mathrm{HClO}_{4}$. A ${ }^{149} \mathrm{Sm}_{-}{ }^{150} \mathrm{Nd}$ spike solution was added to all samples before dissolution. REEs were separated on BioRad AGW50-X8 200-400 mesh resin using conventional cation-exchange techniques. Sm and $\mathrm{Nd}$ were separated by extraction chromatography with a LN-Spec (100-150 mesh) resin. The total blank in the laboratory was $0.1-0.2 \mathrm{ng}$ for Sm and 0.1-0.5 ng for Nd. Isotopic compositions of Sm and Nd were determined on a TRITON TI multicollector mass-spectrometer. The precision $(2 \sigma)$ of $\mathrm{Sm}$ and $\mathrm{Nd}$ contents and ${ }^{147} \mathrm{Sm} /{ }^{144} \mathrm{Nd}$ ratios were $0.5 \%$ and $0.005 \%$ for ${ }^{143} \mathrm{Nd} /{ }^{144} \mathrm{Nd}$ ratios. ${ }^{143} \mathrm{Nd} /{ }^{144} \mathrm{Nd}$ ratios were adjusted relative to a value of 0.512115 for the JNdi-1standard. During the period of analysis, the weighted average of $10 \mathrm{JNdi}-1$ $\mathrm{Nd}$ standard runs yielded $0.512108 \pm 7(2 \sigma)$ for ${ }^{143} \mathrm{Nd} /{ }^{144} \mathrm{Nd}$, normalized against ${ }^{146} \mathrm{Nd} /{ }^{144} \mathrm{Nd}=$ 0.7219 . The $\varepsilon_{\mathrm{Nd}}(t)$ values were calculated using the present-day values for a chondritic uniform reservoir (CHUR) ${ }^{143} \mathrm{Nd} /{ }^{144} \mathrm{Nd}=0.512638$ and ${ }^{147} \mathrm{Sm} /{ }^{144} \mathrm{Nd}=0.1967$ (Jacobsen and Wasserburg, 1984). Whole-rock $\mathrm{Nd}$ model ages $\mathrm{T}_{\mathrm{Nd}(\mathrm{DM})}$ were calculated using the model of Goldstein and Jacobsen (1988) according to which the $\mathrm{Nd}$ isotopic composition of the depleted mantle evolved linearly since $4.56 \mathrm{Ga}$ ago and has a present-day value $\varepsilon \mathrm{Nd}(0)$ of $+10\left({ }^{143} \mathrm{Nd} /{ }^{144} \mathrm{Nd}=0.513151\right.$ and ${ }^{147} \mathrm{Sm} /{ }^{144} \mathrm{Nd}=0.21365$ ). Two-stage (crustal) $\mathrm{Nd}$ model ages $\mathrm{T}_{\mathrm{Nd}(\mathrm{C})}$ were calculated using a mean crustal ratio ${ }^{147} \mathrm{Sm} /{ }^{144} \mathrm{Nd}$ of 0.12 .

\section{Results}

\subsection{Petrography}

The most abundant igneous rock types in the study area are granite, granodiorite, syenogranite, quartz monzonite andesite, and trachyandesite (Fig. 3). Mineral assemblages of representative samples are given in Table 1. The major constituent minerals in undifferentiated 
granodiorite (sample D0925) are plagioclase ( 44\%), quartz ( 25\%), K-feldspar ( 25\%) (Fig. 3a). The accessory minerals are magnetite, apatite, and zircon ( 1\%). Batkhaan inequigranular syenogranite (sample D1710) possesses hypidiomorphic texture with myrmekite intergrowths (Fig. 3b). Major minerals are anhedral quartz ( 40\%), euhedral to subhedral perthitic K-feldspar (phenocrysts of microcline or orthoclase in an amount of $\sim 39 \%)$, subhedral plagioclase ( 20\%). In places, the phenocrysts contain minor fractures filled by quartz and partly affected by sericitization. Zircon, apatite, opaque minerals are accessories ( $1 \%)$. Batkhaan rhyolites are massive and porphyritic and contain $\sim 20 \%$ subhedral-anhedral quartz $\sim 20 \%$ and subhedral-anhedral K-feldspar phenocrysts in a groundmass consisting of quartz, plagioclase, and K-feldspar (Fig. 3c).

Delgerkhaan plutonic rocks are dominated by granite, granodiorite, and quartz monzonite. Hypidiomorphic monzogranite (sample D1742) consists of euhedral to subhedral plagioclase ( $30 \%)$, subhedral K-feldspar ( 30\%), euhedral quartz ( 20\%), biotite $(\sim 13 \%)$, and hornblende ( $~ 5 \%)$, (Fig. 3d) plus accessory zircon, apatite, and titanite ( 2\%). Hypidiomorphic granodiorite (sample D0815) consists of plagioclase ( 45\%), K-feldspar ( 20\%), subhedral quartz ( 15\%), hornblende $(\sim 10 \%)$ and biotite ( $8 \%)$ (Fig. 3e, f) plus accessory zircon and opaque minerals and secondary sericite and chlorite ( $2 \%)$. The Zambalkhudag coarse-grained granodiorite (sample D1726) consists of subhedral plagioclase ( 39\%), euhedral to subhedral K-feldspar $(\sim 20 \%)$ and anhedral quartz ( 20\%), hornblende ( 10\%) and biotite ( 10\%) plus secondary chlorite (Fig. $3 \mathrm{~g}, \mathrm{~h})$. In places, plagioclase and K-feldspar form myrmekite textures. Accessory minerals are zircon and apatite $(\sim 1 \%)$. The volcanic rocks associated with the Delgerkhaan pluton are dominated by porphyry andesite and trachyandesite. Andesite (Sample D1737) contains $0.2-1 \mathrm{~mm}$ long subhedral phenocrysts of plagioclase ( $\sim 50 \%)$ partly replaced by sericite (Fig. 3i). The groundmass ( $50 \%)$ consists of K-feldspar, plagioclase laths, biotite, and secondary chlorite and hornblende (Fig. 3i).

\section{$4.1 \mathrm{U}-\mathrm{Pb}$ geochronology}

The separated zircon grains are stubby to elongated and euhedral to subhedral. Their sizes range from 50 to $300 \mu \mathrm{m}$ and the aspect ratio vary from 1.5 to 3 . The grains are transparent, mostly colorless or yellowish to brownish. In CL images most grains exhibit fine to coarse banded oscillatory zoning (Fig. 4), although there are also zircons with patchy or sectorial zoning. The undifferentiated granitoids have one zircon grain with $498 \mathrm{Ma}$, and the rest of the zircons yielded $\mathrm{U}-\mathrm{Pb}$ zircon concordia age of $296 \pm 3 \mathrm{Ma}$ (Fig. 5). The Batkhaan volcano-plutonic suite carries zircons whose $\mathrm{U}-\mathrm{Pb}$ concordia ages range from 282 to $274 \mathrm{Ma}$. The concordia ages of zircons from the samples of the Delgerkhaan volcano-plutonic suite and Zambalkhudag pluton are bracketed 
between 220 and $224 \mathrm{Ma}$. Zircon features of each sample and their yielded ages are listed in Table 2. Zircon dating results are shown in Supplementary Table 2.

\subsection{Whole-rock geochemistry}

\subsubsection{Undifferentiated granitoids}

The major and trace element geochemical data of the studied samples are given in Supplementary Table 3. The undifferentiated granitoids of the study area are characterized by medium $\mathrm{SiO}_{2}(65.7-66.7 \mathrm{wt} \%), \mathrm{Al}_{2} \mathrm{O}_{3}(15.0-16.7 \mathrm{wt} \%)$, and low $\mathrm{TiO}_{2}(0.39-0.61 \mathrm{wt} \%)$. The contents of $\mathrm{MgO}$ and $\mathrm{FeO}^{\mathrm{T}}$ range from 0.61 to 1.29 and from 2.58 to $3.94 \mathrm{wt} \%$, respectively, resulting in $\mathrm{Fe}$ numbers of 0.75 to $0.83\left[\mathrm{Fe} \#=\mathrm{FeO}^{\mathrm{T}} /\left(\mathrm{FeO}^{\mathrm{T}}+\mathrm{MgO}\right)\right]$ and $\mathrm{Mg}$ numbers of 44 to 56 $[\mathrm{Mg} \#=$ molar $100 \times \mathrm{Mg} /(\mathrm{Mg}+\mathrm{Fe})]$. The total alkalis $\left(\mathrm{Na}_{2} \mathrm{O}+\mathrm{K}_{2} \mathrm{O}\right)$ are high $(7.9-8.3 \mathrm{wt} \%)$, in the TAS diagram they plot in the field of quartz monzonite (Fig. 6a). The rocks are ferroan to magnesian (Fig. 6c) and high-K calc-alkaline (Fig. 6d). They belong to I-type granites, and the ratio of $\mathrm{A} / \mathrm{CNK}\left[\mathrm{molar} \mathrm{Al}_{2} \mathrm{O}_{3} /\left(\mathrm{CaO}+\mathrm{K}_{2} \mathrm{O}+\mathrm{Na}_{2} \mathrm{O}\right)\right]$ ranges from 0.94 to 1.04 indicating their metaluminous to the weakly peraluminous character (Fig. 7b). The rocks exhibit high concentrations of $\mathrm{Sr}(519-1377 \mu \mathrm{g} / \mathrm{g})$ and low concentrations of $\mathrm{Y}(9.9-18.7 \mu \mathrm{g} / \mathrm{g})$ and $\mathrm{Yb}(0.75-$ $1.87 \mu \mathrm{g} / \mathrm{g})$. In addition, they have low $\mathrm{Cr}(<20 \mu \mathrm{g} / \mathrm{g})$, and $\mathrm{Ni}(<20 \mu \mathrm{g} / \mathrm{g})$. The degree of LREE and HREE differentiation is moderate to high with $\left[(\mathrm{La} / \mathrm{Yb})_{\mathrm{CN}}=11-32\right]$ (Fig. 8a). The REE patterns show weak negative to zero Eu anomalies. The primitive mantle-normalized multi-element patterns show enrichment in incompatible elements and positive $\mathrm{Nb}$ anomalies relative to $\mathrm{Th}$ and $\mathrm{La}$ (Fig. $8 b)$.

\subsubsection{Batkhaan volcano-plutonic rocks}

The Batkhaan granitoids geochemically consist of granites and monzonites (Fig. 6a). The $\mathrm{SiO}_{2}$ content of the Batkhaan granitoids are spans 72.9-77.2 $\mathrm{wt} \%$, and total alkalis are 7.46-9.77 wt $\%$. The rocks have low $\mathrm{Al}_{2} \mathrm{O}_{3}(11.3-14.9 \mathrm{wt} \%), \mathrm{Mg} \#(14-39)$, and $\mathrm{CaO}(0.08-0.78 \mathrm{wt} \%)$, but high Fe\# (0.86-0.96 wt\%), i.e., they represent ferroan rocks and normal to high-K calc-alkaline (Fig. 6c, d). Compared to the granites, the monzonites have lower $\mathrm{SiO}_{2}(59.5-61.4 \mathrm{wt} \%$ ) and total alkalis (6.86-7.72 wt\%), but higher $\mathrm{Al}_{2} \mathrm{O}_{3}(16.6-19.7 \mathrm{wt} \%)$ and $\mathrm{Mg} \#(26-36)$ and $\mathrm{CaO}(3.4-5.9$ $\mathrm{wt} \%$ ). The volcanic rocks are dominantly rhyolite except for one sample of dacite (Fig. 6b). They belong to A-type granites (Fig. 7a, b) and their A/CNK values range from 0.95 to 1.13 , indicating peralkaline, metaluminous, and peraluminous transition character (Fig. 7c). They have high $\mathrm{SiO}_{2}=$ 67.9-77.6 wt \%, and total alkalis $=6.5-8.8 \mathrm{wt} \%$, but low $\mathrm{Al}_{2} \mathrm{O}_{3}(11.2-13.6 \mathrm{wt} \%), \mathrm{Mg} \#(10-39)$, and $\mathrm{CaO}(0.05-1.75 \mathrm{wt} \%)$. All Batkhaan rocks, both plutonic and volcanic, have slightly LREE enriched $\left[(\mathrm{La} / \mathrm{Yb})_{\mathrm{CN}}=2.8-6.6\right.$, except $\left.\mathrm{D} 1721=23.5\right]$ with clear troughs at Eu (Fig. 8c). They are 
enriched in $\mathrm{Nb}(0.8-25 \mu \mathrm{g} / \mathrm{g}), \mathrm{Zr}(71-411 \mu \mathrm{g} / \mathrm{g}), \mathrm{Y}(3.6-56 \mu \mathrm{g} / \mathrm{g}), \mathrm{U}(0.82-4.91 \mu \mathrm{g} / \mathrm{g})$, and $\mathrm{Ta}(0.2-$ $1.79 \mu \mathrm{g} / \mathrm{g}$ ), but depleted in $\mathrm{Sr}(17-263 \mu \mathrm{g} / \mathrm{g}$ in granites and $245-456 \mu \mathrm{g} / \mathrm{g}$ in monzonites). The primitive mantle normalized spidergrams of the Batkhaan rocks show deep troughs at $\mathrm{Ba}, \mathrm{Sr}, \mathrm{P}, \mathrm{Eu}$, and $\mathrm{Ti}$ and shallower troughs at $\mathrm{Nb}$ and $\mathrm{Ta}$ (Fig. 8d).

\subsubsection{Delgerkhaan volcano-plutonic rocks}

Previous researchers considered the Delgerkhaan and Zambalkhudag plutons as different (Tumurchudur et al., 2006). In this paper, we characterize them together since they possess similar geochemical features. The rocks of the Delgerkhaan and Zambalkhudag plutons span wide ranges of $\mathrm{SiO}_{2}(61.4-75 \mathrm{wt} \%)$ and total alkalis $\left(\mathrm{Na}_{2} \mathrm{O}+\mathrm{K}_{2} \mathrm{O}=6.3-9.4 \mathrm{wt} \%\right)$, a restricted range of $\mathrm{Al}_{2} \mathrm{O}_{3}$ (12.9-16.60 wt\%). Most of the samples are characterized by high $\mathrm{TiO}_{2}(0.03-0.82 \mathrm{wt} \%)$, moderate $\mathrm{FeO}^{\mathrm{T}}$ (1.0-5.3 wt\%), and high $\mathrm{Mg} \#$ (44-73) except for three samples with lower Mg\# (2.85-24). In the TAS diagram, the granitoids fall in the fields of granodiorite, quartz monzonite, and granite (Fig. 6a). As Fe\# ranges from 0.53 to 0.99 , the granitoids belong to the magnesian type and high-K cal-alkaline series granites (Fig. 6c, d). The samples plot on the I-type granite field (Fig. 7a, b) and in the $\mathrm{A} / \mathrm{CNK}$ versus the $\mathrm{A} / \mathrm{NK}$ diagram, the samples plot in the metaluminous and I-type fields (Fig. 7c, d). The chondrite normalized REE patterns show fractionated LREE $\left[(\mathrm{La} / \mathrm{Gd})_{\mathrm{CN}}=2.1-\right.$ 9.7], less fractionated HREE $\left[(\mathrm{Gd} / \mathrm{Yb})_{\mathrm{CN}}=1.2-6.5\right]$, and weak to zero negative or positive $\mathrm{Eu}$ anomalies (Fig. 8e). The spidergrams show enrichment in LILEs and depletion in HFSEs. They display lower contents of $\mathrm{Nb}, \mathrm{Zr}, \mathrm{Y}$, and $\mathrm{U}$ but higher $\mathrm{Sr}$ and $\mathrm{Pb}$ (Fig. 8f). The samples are characterized by high $\operatorname{Sr}(168-598 \mu \mathrm{g} / \mathrm{g})$, and low $\mathrm{Y}(6.1-35 \mu \mathrm{g} / \mathrm{g})$, and $\mathrm{Yb}(1.09-4.04 \mu \mathrm{g} / \mathrm{g})$. The volcanic rocks associated with the Delgerkhaan pluton have $\mathrm{SiO}_{2}=58.5-68.1, \mathrm{MgO}=0.50-7.4$, $\mathrm{Al}_{2} \mathrm{O}_{3}=13.6-16.2, \mathrm{TiO}_{2}=0.6-1 \mathrm{wt} \%, \mathrm{FeO}^{\mathrm{T}}=4.16-7.4,\left(\mathrm{Na}_{2} \mathrm{O}+\mathrm{K}_{2} \mathrm{O}\right)=5.18-8.6$ wt. \%. The values of $\mathrm{Mg} \#$ and Fe\# are bracketed between 22 and 79, 0.5 and 0.93, respectively. The volcanic rocks are andesite, trachyandesite, trachydacite, and dacite (Fig. 6b). According to A/CNK (0.771.07), they represent metaluminous to peraluminous varieties (Fig. 7c). The chondrite normalized REE patterns (Fig. 7a) show enrichment in LREEs $\left[(\mathrm{La} / \mathrm{Yb})_{\mathrm{CN}}=2.88-34.6\right]$, and weak negative to positive Eu anomalies. The multi-element patterns show negative $\mathrm{Nb}$ and Ti anomalies (Fig. 8e) and significant enrichment in LILE (K, Rb, Ba, Sr) (Fig. 8f).

\subsection{Zircon Hf isotopes}

Seven analyses from sample D0925 gave initial ${ }^{176} \mathrm{Hf} /{ }^{177} \mathrm{Hf}$ ratios $(t=296 \mathrm{Ma})$ varying from 0.282488 to 0.282654 , among which one analysis on an inherited zircon grain with an age of $\sim 498$ Ma yielded initial ${ }^{176} \mathrm{Hf} /{ }^{177} \mathrm{Hf}$ ratios $(t=498 \mathrm{Ma}$ ) of 0.282488 (Supplementary Table 4). Their $\varepsilon \mathrm{Hf}(t)$ values and two-stage model ( $\left.\mathrm{T}_{\mathrm{DM} 2}\right)$ ages range from -2.26 to +2.6 and from 1168 to 1527 
Ma, respectively. The initial ${ }^{176} \mathrm{Hf} /{ }^{177} \mathrm{Hf}$ ratios for 15 spots of the $\sim 280 \mathrm{Ma}$ Batkhaan granitoids and associated rhyolites (samples D1710 and D1709, respectively) vary from 0.282664 to 0.282918 . The corresponding $\varepsilon \mathrm{Hf}(t)$ values and two-stage model ages $\mathrm{T}_{\mathrm{DM} 2}$ vary from 2.14 to 11.22 and 581 to 1159, respectively. Twenty-one analyses of three samples from the 220-240 Ma Delgerkhaan granites (samples D1718, D1726, and D1742) yielded initial ${ }^{176} \mathrm{Hf} /{ }^{177} \mathrm{Hf}$ ratios from 0.282684 to 0.282830 , which are translated into $\varepsilon \mathrm{Hf}(t)$ values from +1.9 to +7.09 and $\mathrm{T}_{\mathrm{DM} 2}$ between 810 and $1139 \mathrm{Ma}$, respectively.

\subsection{Sm-Nd isotopic analysis}

The Sm-Nd isotopic analysis was carried out for 5 selected samples. One sample from each granitic massif, and one from the Batkhaan rhyolite. The $\varepsilon_{\mathrm{Nd}}(t)$ values are calculated using the zircon $\mathrm{U}-\mathrm{Pb}$ concordant ages of each sample. The sample from undifferentiated granitoids has $\varepsilon_{\mathrm{Nd}}(t)$ $=-1.7$ and corresponds to $\mathrm{T}_{\mathrm{Nd}(\mathrm{DM})}=1076$ and $\mathrm{T}_{\mathrm{Nd}(\mathrm{C})}$ ages of $1262 \mathrm{Ma}$ (Supplementary Table 4). The Batkhaan granite and rhyolite have higher $\varepsilon_{\mathrm{Nd}}(t)$ values varying from +2.7 to +4 . 1 . They have $\mathrm{T}_{\mathrm{Nd}(\mathrm{DM})}$ model ages of 762-993 Ma and $\mathrm{T}_{\mathrm{Nd}(\mathrm{C})}$ model ages of 725-838 Ma. The remained samples exhibit $\varepsilon_{\mathrm{Nd}}(t)$ values ranging from -0.7 to +1.7 corresponding to $\mathrm{T}_{\mathrm{Nd}(\mathrm{DM})}$ model ages of $697-1509$ Ma and $\mathrm{T}_{\mathrm{Nd}(\mathrm{C})}$ model ages of 893-1073 Ma.

\section{Discussion}

\subsection{Three groups of granitoid magmatism}

Our new $\mathrm{U}-\mathrm{Pb}$ age results allow us to recognize three groups of magmatism in the Delgerkhaan area from the Early Permian until the Late Triassic: at $\sim 296, \sim 280$, and $\sim 230$ Ma. The Group I formed at 296 \pm 3 Ma intrusion was previously considered as Late Cambrian (Dagvadorj et al., 1993), but our new data show that it has Early Permian age. Moreover, the granitoids contain Late Cambrian (Furongian) inherited zircons ( $498 \mathrm{Ma}$ ), implying that melt is including zircons that crystallized in the past. Group II includes the Batkhaan granite, monzonites, and associated rhyolites of $282 \pm 3$ and $274 \pm 2 \mathrm{Ma}$, respectively (Fig. 5). These ages are generally consistent with the age of $282 \pm 16 \mathrm{Ma}$, previously reported for the granodiorite although with a large error (AmarAmgalan, 2008). Group III comprises the Delgerkhaan pluton of 230-240 Ma. The Zambalkhudag pluton was previously speculated as Late Carboniferous, as it intrudes Devonian sandstones containing fauna (Tumurchudur et al., 2006 and reference therein), however, our data show that it formed at $220 \pm 2 \mathrm{Ma}$. Thus, we suggest that the Zambalkhudag pluton is coeval and related to the Delgerkhaan pluton as they possess similar geochemical and isotopic features and close crystallization ages (Table 2; Figs. 5, 6). This group of magmatism also includes associated $\sim 223$ Ma (K-Ar) of intermediate volcanics (Dagvadorj et al., 1993). 


\subsubsection{Group I ( 296 Ma granitoids)}

Group I granitoids are metaluminous to peraluminous and have an I-type trend in the Th versus $\mathrm{Rb}$ diagram (Figs. 6, 7c). Two samples have elevated Rb, K, U, and Th concentrations and low $\mathrm{MgO}, \mathrm{Cr}$, and $\mathrm{Ni}$ contents implying crustal compositional affinities. In addition, the values of $\mathrm{Nb} / \mathrm{Ta}(9.4-11)$ and $\mathrm{Zr} / \mathrm{Hf}$ (38-39) differ from those of the primitive mantle $(\mathrm{Nb} / \mathrm{Ta}=17.8 ; \mathrm{Zr} / \mathrm{Hf}=$ $45)$, and closer to the crustal values $(\mathrm{Nb} / \mathrm{Ta}=11 ; \mathrm{Zr} / \mathrm{Hf}=33)$, thereby supporting a crustal source for their parental magma. Their chondrite-normalized REE patterns are enriched in the LREEs, depleted in the HREEs, and show no Eu and Sr anomalies (Fig. 8a) precluding fractionation of plagioclase. The primitive-mantle normalized multi-element patterns show pronounced negative anomalies at $\mathrm{Nb}$, Ta, and $\mathrm{Ti}$ (Fig. 8b), which are typical of supra-subduction igneous rocks. Nevertheless, one sample has low $\mathrm{K}_{2} \mathrm{O}, \mathrm{U}$, Th, and their $\mathrm{Nb} / \mathrm{Ta}$ (16) and $\mathrm{Zr} / \mathrm{Hf}$ (45) ratios are closer to those of the primitive mantle. Although the number of samples is not enough to discuss their petrogenesis in detail, we suggest that the undifferentiated body of Group I may consist of granitic bodies derived from two types of sources: felsic (recycled) and mafic (mixed or juvenile). The two granitoids of Group I have mostly negative values of $\varepsilon_{\mathrm{Nd}}(t)(-1.7)$ and $\varepsilon_{\mathrm{Hf}}(t)(-3.57$ to +2.3$)$, and Neoproterozoic to Mesoproterozoic modal ages implying the presence of ancient crust material in their source (Fig. 9a, b).

\subsubsection{Group II (Batkhaan)}

In Group II, we consider the Early Permian Batkhaan granitoids, monzonites, and rhyolites together as they have close ages and similar geochemical features (Figs. 6, 7; Supplementary Table 3) and therefore they probably formed in similar tectonic settings. The Group II rock association is characterized by high total alkalis, Fe\#, Ga/Al, HFSE (Zr, Nb, and Y) and REEs low CaO, Ba, and Sr, and clear negative Eu anomaly (Fig. 8c, d). These features suggest that they have characteristics similar to A-type granites (Fig. 7a, b). The origin, evolution, and tectonic settings of formation/emplacement of A-type granites remain debatable though (e.g., Bonin, 2007). They can be produced by: (1) fractionation of mantle-derived magmas with or without interaction with crustal rocks (Turner et al., 1992); (2) low degrees of partial melting of lower crustal or underplated basaltic magma (Jones et al., 2018); (3) hybrid magma from the mantle and crustal derived melts and metasomatism of granitic magmas (Taylor and McLennan, 1995).

The Group II rocks show no coeval mafic igneous rocks, as should be expected for extensive fractional crystallization. Restricted variations of zircon $\varepsilon \mathrm{Hf}(t)$ values exclude the mixing of mantle- 
derived and crust-derived melts as that would have generate melts with scattered isotopic signatures (e.g., Kemp et al., 2007). The low Nb, Ta, and Ti and high Th, U, and Pb contents, high trace element ratios of $\mathrm{Th} / \mathrm{Ce}(0.18-0.31)$ and $\mathrm{Th} / \mathrm{La}(0.4-0.86)$ ratios suggesting a significant contribution of the continental crust during their generation. The monzonites of Group II show different geochemical characteristics, such as the lack of Eu anomaly, the low contents of $\mathrm{K}_{2} \mathrm{O}$, Th and $\mathrm{Rb}$, and $\mathrm{Th} / \mathrm{Ce}(0.11-0.14)$ and $(\mathrm{Th} / \mathrm{La})(0.24-0.29)$ ratios lower than those in granites and rhyolites and closer to those of basaltic rocks (Rudnick and Gao, 2003). We suggest that the Group II monzonites formed through the partial melting of a mafic source.

Experimental data indicate that metaluminous and peraluminous A-type magmas like Group II granites and rhyolite samples can be produced by the melting of calc-alkaline tonalite and granodiorite at shallow depths (4 kbar) and high temperatures $\left(950{ }^{\circ} \mathrm{C}\right)$ (Patiño Douce, 1997). In fact, the low $(\mathrm{La} / \mathrm{Yb})_{\mathrm{CN}}$ ratios as well as the pronounced negative anomalies of $\mathrm{Ba}, \mathrm{Eu}$, and $\mathrm{Sr}$ (Fig. $8 \mathrm{c}, \mathrm{d})$ of Group II rhyolites and granites with metaluminous to peraluminous compositions indicate that they formed at shallow crustal depths (Bonin, 2007). Group II rocks exhibit the positive value of $\varepsilon_{\mathrm{Hf}}(t)(+2.14$ to +9.76$)$ and $\varepsilon_{\mathrm{Nd}}(t)(+2.7$ to +4.1$)($ Fig. $8 \mathrm{~b})$ and corresponding two-stage model ages suggesting that the primary magma crystallized from a Neoproterozoic juvenile source. The high temperatures of melting required to produce A-type rocks were probably provided by the underplating of juvenile mafic magmas, which fed the melting of the monzonites in the lower crust and granites and rhyolites at a shallow crustal depth.

\subsubsection{Group III (Delgerkhaan)}

Delgerkhaan granitoids and the Triassic volcanics show similar ages and geochemical features. The Group III calc-alkaline samples have high-K, Rb, U, and Th (Figs. 6d; 8e, f). However, compared to Group I, the Group III samples have higher $\mathrm{Mg}, \mathrm{Cr}$, and $\mathrm{Ni}$, suggesting a deeper and/or more mafic source of melting. The absence of contemporaneous mafic microgranular enclaves excludes extremal fractional crystallization of mantle-derived magma. Their high $\mathrm{Sr} / \mathrm{Y}$ ratio and fractionated REE pattern suggest the presence of minerals with high partition coefficients for HREE, i.e., garnet or hornblende, in the residue. The melts that equilibrate with residual garnet would have steep HREE distribution patterns and a high ratio of $\mathrm{Yb} / \mathrm{Lu}$ (>10; Moyen, 2009). However, the Group III rocks show moderately steep REE distribution patterns (Fig. 8e, f) and relatively low $\mathrm{Yb} / \mathrm{Lu}(5-7)$ ratios excluding the presence of garnet in the residue. The Group III REE patterns are moderately concave-upward between the MREEs and HREEs as typical of hornblende-bearing sources as hornblende is relatively MREE-rich (Macpherson et al., 2006), as can be seen on. The lower $\mathrm{Nb} / \mathrm{Ta}$ and $\mathrm{SiO}_{2}$ (Fig. 10a) can be explained by the fractionation of 
hornblende (Tiepolo and Vannucci, 2014). More evidence for the fractionation of hornblende comes from the Dy versus Er diagram (Fig. 10b).

The values of Fe\# in the Group III rocks are relatively low (average $=0.68$ ) compared to other groups (Fig. 6c; Frost et al., 2001). Such low Fe\# granitoids are common in the Cordilleran batholiths $(<0.6)$ and even in the Caledonian post-orogenic granites $(\sim 0.5)$. As Fe\# is strongly affected by differentiation during magma ascent (Frost et al., 2001), and early crystallization of Febearing mineral phases would inhibit iron enrichments during differentiation. In case of Group III granitoids, we suggest that fractional crystallization of hornblende provided the formation of peraluminous I-type granitoids with lower Fe\# (Chappell et al., 2012).

Diagrams $\mathrm{La} / \mathrm{Yb}$ versus $\mathrm{La}$ and $\mathrm{Zr} / \mathrm{Nb}$ versus $\mathrm{Zr}$ can be used to evaluate the effect and degree of fractional crystallization and partial melting on compositional variations in magmas. The sample points form trends parallel to the array of partial melting (Fig. 11a, b) suggesting that partial melting played a greater role than fractional crystallization. The $\mathrm{Nb} / \mathrm{Zr}$ versus $\mathrm{Th} / \mathrm{Zr}$ (Fig. 11c) and $\mathrm{Nb} / \mathrm{Y}$ versus $\mathrm{Rb} / \mathrm{Y}$ (Fig. 11d) systematics also confirm the participation of subducted slab-derived fluids during the magma generation.

The combination of these features with the enrichment of Group III rocks in LREEs and LILEs and depletions in HREEs and HFSEs (Fig. 8e, f) suggests that these rocks resulted from the partial melting of lower crustal source with hornblende in residue and participation of subductionrelated fluids. As the Group III samples are characterized by positive $\varepsilon_{\mathrm{Hf}}(t)$ and positive to negative $\varepsilon_{\mathrm{Nd}}(t)$ (Fig. 9a, b), and Neoproterozoic two-stage model ages, we conclude that their primary magma originated by the partial melting of Neoproterozoic depleted lower crust.

\section{$5.3 \mathrm{Nd}$-Hf isotope decoupling}

$\mathrm{Hf}$ and $\mathrm{Nd}$ crustal modal ages of studied three group samples exhibit that pre-existing juvenile material contribution was Mesoproterozoic and mainly Neoproterozoic (Fig. 12a). The values of $\varepsilon \mathrm{Hf}(t)$ for zircons from the rocks of the Group II and III deviate positively from the whole-rock $\varepsilon_{\mathrm{Nd}}(t)$ values compared to the normal terrestrial arrays for the mantle and crust $\mathrm{Nd}-\mathrm{Hf}$ isotope evolution (Fig. 12b; Vervoort et al., 1999) suggesting Nd-Hf isotope decoupling (e.g., Schmitz et al., 2004). There are three main explanations for the decoupled Nd-Hf isotopic compositions in the granitoids under consideration. The first implies the presence of garnet capable to decouple $\mathrm{Nd}$ and $\mathrm{Hf}$ isotopes in the source (Schmitz et al., 2004). As Lu in garnet has a higher coefficient of distribution compared to $\mathrm{Sm}, \mathrm{Nd}$, and $\mathrm{Hf}$, residual garnet can retain $\mathrm{Lu}$ over time and produce high ${ }^{176} \mathrm{Hf} /{ }^{177} \mathrm{Hf}$ melt reservoirs. The magmas derived from such garnet-bearing residual assemblages may have higher ${ }^{176} \mathrm{Hf} /{ }^{177} \mathrm{Hf}$ relative to ${ }^{143} \mathrm{Nd} /{ }^{144} \mathrm{Nd}$. No evidence for residual garnet was exhibited in the Group II and III rock associations and it rules out this model. 
Another hypothesis explains such decoupling by the melting of a meta-sedimentary source with a high $\mathrm{Lu} / \mathrm{Hf}$ ratio because of the "zircon effect". As zircon is resistant to weathering it can preserve its primary magmatic Hf isotopic composition (Rubatto and Hermann, 2003). The retention of radiogenic $\mathrm{Hf}$ in igneous zircons is possible during the partial melting of juvenile crustal material (Patchett and Tatsumoto, 1981). Zircons retain Hf isotope signatures, acquired during their crystallization from an earlier magma, whereas the whole-rock Sm-Nd system is typically equilibrated with later melts and hence produces lower $\varepsilon_{\mathrm{Nd}}(t)$ values (Wu et al., 2006). As a result, the granites have less radiogenic whole-rock $\mathrm{Nd}$ isotope compositions than the normal terrestrial rocks at a given value of $\varepsilon_{\mathrm{Hf}}(t)$ in zircon. Such a scenario for the decoupling of zircon $\mathrm{Hf}$ and whole-rock Nd isotopes can be attributed to the Group II granitoids. These granitoids have high $\mathrm{Lu} / \mathrm{Hf}$ ratios of 0.07 to 0.11 , i.e. similar to those of meta-sedimentary rocks, 0.09 to 0.11 (Eroğlu et al., 2013), suggesting the participation of sediments. The crustal extension could involve sediments into magma generation, and change the proportion of $\mathrm{Hf}$ and $\mathrm{Nd}$ isotopes in the melt. However, this scenario cannot be responsible for Group III rock association as they have lower Lu/Hf ratios $(0.02-$ 0.07) than meta-sedimentary sources.

An alternative hypothesis is the partial melting of decoupled Nd-Hf-bearing lithospheric mantle or juvenile lower crust. This hypothesis defends that decoupled compositions are inherited from the interaction between fluids (with high $\mathrm{Nd} / \mathrm{Hf}$ ratios from subducting sediments or oceanic crust) and the lithospheric mantle (Chauvel et al., 2009) as Hf is less mobile in slab-derived fluid than $\mathrm{Nd}$ resulting in the re-enrichment of $\mathrm{Nd}$ isotopes. Consequently, fluids extracted from subducted sediments or slabs and affecting the mantle wedge would generate melts with high $\varepsilon_{\mathrm{Hf}}(t)$ and low $\varepsilon_{\mathrm{Nd}}(t)$ (Chauvel et al., 2009). We consider such a fluid-mantle interaction as a reason for the Nd-Hf decoupled composition of the Group III rocks.

\subsection{Tectonic model}

The geochemical and isotope compositions of the three groups of igneous rocks of the Khangay-Khentey basin in the Central Mongolia suggest different tectonic settings of their emplacement. The tectonic setting of the formation of Group I rocks remains enigmatic as we have data from three samples only. In the tectonic discrimination $\mathrm{Nb}$ versus $\mathrm{Y}$ and $\mathrm{Rb}$ versus $\mathrm{Y}+\mathrm{Nb}$ diagrams, most samples of Group II plot in the field of post-collisional granites (Fig. 13a). However, the post-collisional setting is an unlikely hypothesis since, so far, no evidence of collision has been found in the adjacent areas, e.g., significant crustal thickening, abundant S-type granites, etc. Moreover, the amount of outcropped A-type granites and rhyolites in the study area is relatively small, although post-collisional settings are characterized by compositionally variable and huge volume of granitoids. The Group II samples show high $\mathrm{Ce} / \mathrm{Nb}, \mathrm{Y} / \mathrm{Nb}$, and $\mathrm{Ga} / \mathrm{Nb}$ ratios and 
therefore represent $\mathrm{A}_{2}$-type granitoids (Fig. 14a, b). Felsic igneous rocks formed at convergent margin settings may also exhibit A-type signatures. For example, the A-type granites of the Lachlan Belt in eastern Australia were emplaced in a back-arc extensional setting in response to slab rollback (e.g., Collins et al., 2020). Although the petrogenesis of Group II (A2-type) may support such a scenario, we think the magmatism found is not sufficiently important. Usually, a back-arc extension setting is precluded by a vast subduction-related granitoid batholiths emplacement, like those of the Eastern Sikhote-Alin or the Andes. The Group I granitoids are older than the Group II ones, but the outcrops of the former are small and pre-Early Permian granitic bodies are scarce in Central Mongolia as well (Fig. 1c). Therefore, we assume that the Group II rocks emplaced in a setting of local extension possibly linked with magma underplating and /or asthenospheric upwelling.

The Group III high-potassium calc-alkaline I-type granitoids with low Fe\# could be emplaced in two tectonic settings: (1) Andean-type active continental margin, (2) post-collisional (Frost et al., 2001). The Group III granites are compositionally close to andesite and trachyandesite (Fig. 2), and enriched in LREEs and LILEs, but depleted in HFSEs (e.g., Nb, Ta, and Ti) (Fig. 7, 8). In the $\mathrm{Nb}$ versus $\mathrm{Y}$ (Fig. 13a) and $\mathrm{Th} / \mathrm{Yb}$ versus $\mathrm{Ta} / \mathrm{Yb}$ (Fig. 13b) diagrams, they plot in the volcanic arc granite field and active continental margin field, respectively. These characteristics suggest their emplacement in a subduction-related tectonic setting, although post-collisional granites also show arc-like trace element signatures due to the contribution of subduction-related materials from previous tectonic events. However, recent studies have shown that the MongolOkhotsk Ocean remained open until the Middle Triassic. The evidence for this comes from: (1) Middle Triassic subduction-related magmatism manifested on its both sides, northern (e.g., Donskaya et al., 2013) and southern (e.g., Zhu et al., 2016; Liu et al., 2018); (2) zircon ages from metasediments (turbiditic and greywacke sandstones) in the eastern part of the Mongol-Okhotsk belt, which peak at $\sim 173 \mathrm{Ma}$, indicating that sedimentation of the Mongol-Okhotsk oceanic basin continued until the Middle Jurassic (e.g., Sorokin et al., 2020); (3) paleomagnetic data from the volcanic rocks of NE Mongolia reveal that the Central Mongolia Block was separated from the Siberian Craton by the $\mathrm{MOO}$ with a $\sim 30^{\circ}$ latitudinal difference in the Early Permian and welded in the Middle Jurassic (e.g., Yi and Meert, 2020); (4) coexistence of Boreal-type realm (northern cold affinity) and Tethyan-type realm (southern warm affinity) Anisian (Middle Triassic) ammonoid fauna in the Khentey province suggests that a wide ocean still existed during the Middle Triassic (Ehiro et al., 2006). The study area lies about $150 \mathrm{~km}$ to the west from Adaatsag ophiolite-a suture of the Mongol-Okhotsk Ocean. Besides, the study area is adjacent to the Central Mongolia-Erguna Block from the south (e.g., Wilhem et al., 2012). Therefore, present-day data do not support a postcollisional origin for Group III rocks. Consequently, we think that an Andean-type active continental margin explains better the characteristics of Group III. 


\subsection{Geodynamic implications}

The three groups of magmatic felsic rocks that crop out in the Khangay-Khentey basin of Central Mongolia formed during the Late Paleozoic to the Early Mesozoic in different tectonic settings. The Late Carboniferous to Early Permian A-type granites and highly alkaline igneous rocks are widely distributed south of the Main Mongolian Lineament (South Mongolia and Inner Mongolia) and have been considered as a part of the Tarim Large Igneous Province (LIP) (Yarmolyuk et al., 2014). However, unlike the Tarim LIP, the Khangay-Khentey lacks alkaline basalt, comendite, pantellerite, or nepheline syenite and $\mathrm{A}_{1}$-type granitoids, which are considered as a result of a mantle plume. Thus, the Batkhaan igneous rocks were emplaced in a setting of weak local extension rather than in relation to a plume-induced rifting. The pre-Permian geological structures of the central CAOB were related to the evolution of the PAO and the subsequent suturing of the MOO (Windley et al., 2007). The Late Paleozoic to Early Mesozoic subduction of the MOO crust formed the magmatic fields outcropped in the Khangay-Khentey region (Fig. 1c) (e.g., Donskaya et al., 2013; Zhao et al., 2017). The northward subduction of the MOO lithosphere beneath the Siberian Craton (including its accreted southern margin) has been well-defined, as indicated by the subduction-related Angara-Vitim granitoids and the Permian-Triassic Selenge volcano-plutonic belt (e.g., Donskaya et al., 2013; Izbrodin et al., 2020). These magmatic belts were emplaced by several episodes during a period from the Late Carboniferous to the Jurassic. Unlike the northern part of Mongolia-Okhotsk suture zone, the tectonic evolution of the southern part has been better reconstructed in the Erguna Belt, NE China (Sun et al., 2013; Liu et al., 2018), and to a lesser extent, in the Khangay Belt (e.g., Dolzodmaa et al., 2020). According to the igneous rock ages, the southern subduction of the Mongol-Okhotsk oceanic crust started in the Carboniferous and continued until the Early-Middle Jurassic (Liu et al., 2018).

$\mathrm{U}-\mathrm{Pb}$ ages, geochemical, and isotope data from Group III granitoids agree with the previous data and indicate a magmatic emplacement in the Early Permian-Late Triassic time. In addition, there is no systematic WE younging of magmatic ages in the southern segment of the MongolOkhotsk Belt (Fig. 1c). Consequently, the Group III rocks probably formed during the southward subduction of the MOO lithosphere in a tectonic setting of an Andean-type active continental margin. Our new data support the idea of the subduction of the Mongol-Okhotsk oceanic crust beneath the Central Mongolia-Erguna Block during the Early Permian-Late Triassic from the Mongolian side.

\section{Conclusions}


Our new U-Pb zircon ages, whole-rock geochemical data, and in situ Hf-in-zircon and whole-rock Sm-Nd isotope characteristics obtained from Late Paleozoic-Early Mesozoic granitoids of Khangay-Khentey basin in Central Mongolia allowed us to conclude the following.

(1) Late Paleozoic-Early Mesozoic granitic rocks in the Khangay-Khentey basin formed at three different times, which were emplaced in Early Permian ( 296 Ma, Group I), middle Permian ( $\sim 280 \mathrm{Ma}$, Group II), and middle Triassic ( $230 \mathrm{Ma}$, Group III), respectively.

(2) Group I includes I-type quartz monzonite and granodiorites derived from crustal (recycled) and mantle (mixed or juvenile) sources and their Cambrian age is superseded.

(3) Group II pluton comprises $A_{2}$-type granites, monzonites, and rhyolites. Monzonites were derived from a mafic source, whereas granites and rhyolites were derived from a source containing Neoproterozoic crustal materials and depleted mantle material. The Group II granitoids were emplaced in a local extension environment linked with magmatic underplating and/or asthenosphere upwelling.

(4) Group III includes I-type granitoids and volcanic rocks. They were generated from partial melting of a juvenile lower crustal source with the contribution of ancient crust. They formed at an Andean-type active continental margin related to the southward subduction of the MongolOkhotsk Ocean beneath the Central Mongolia-Erguna Block.

\section{Acknowledgment}

This research was supported by CNEAS and FRIS of Tohoku University and in part by grants from the MEXT/JSPS KAKENHI JP18H01299 and JP21H01174 to TT and JP19K04043 to KA, by the National Natural Science Foundation of China (grant number 41772230) to L. Miao, and by the Russian Science Foundation (grants 20-77-10051 to Ilya S. and 21-77-20022 to Inna S.). AG gratefully acknowledges the Japanese Government MEXT Scholarship. We also thank Isamu Morita, and Manzshir Bayarbold, Sanchir Dorjgochoo for their assistance in the laboratory and for providing geological material. Contribution to IGCP\#662.

\section{CAPTIONS}

Fig. 1. (a) Tectonic outline of Asia and location of the Central Asian Orogenic Belt (modified from Safonova, 2017). (b) Location of large granitic batholiths in the eastern segment of the CAOB (modified from Yarmolyuk et al., 2002). (c) Late Paleozoic-Early Mesozoic granitoid distribution in Central and Northeastern Mongolia. Published zircon ages are also shown; the references are summarized in Supplementary Table 1. MOB-Mongol-Okhotsk Belt. 
Fig. 2. Simplified geological map of the Delgerkhaan area (modified after the 1:200 000 State Geological Map), showing sample locations.

Fig. 3. Photomicrographs of cross-polarized light view showing textures and mineral assemblage of the studied samples from the Khangay-Khentey basin. (a) Granodiorite (sample D0925); (b) Syenogranite (sample D1710); (c) Rhyolite (sample D1709); (d) Monzogranite (sample D1742); (e) Granodiorite (sample D0815); (f) Granodiorite (sample D0817); (g) Monzogranite (sample D1718); (h) Granodiorite (sample D1726); (f) Andesite (sample D1745). Bt—biotite; Hbl—hornblende; Kfs_K-feldspar; Pl—plagioclase; Qz—quartz; Ms—muscovite.

Fig. 4. Cathodoluminescence (CL) images of representative zircon crystals from the studied samples from the Khangay-Khentey basin. White circles show individual analysis spots, corresponding $\mathrm{Pb}-\mathrm{Pb}$ ages and yellow circles show an individual spot of $\mathrm{Lu}-\mathrm{Hf}$ isotope and their $\varepsilon_{\mathrm{Hf}}(t)$ values.

Fig. 5. Concordia diagrams of zircons for samples from the Khangay-Khentey basin, showing U-Pb isotope ratios. Light grayish ellipses indicates discordant data excluded from the calculation.

Fig. 6. Major element discrimination diagrams showing the compositions and characteristics of the studied samples from Khangay-Khentey basin, Central Mongolia. (a) $\mathrm{SiO}_{2}$ versus $\left(\mathrm{Na}_{2} \mathrm{O}+\mathrm{K}_{2} \mathrm{O}\right)$ total alkali-silica (TAS) diagram for plutonic rocks (after Irvine and Baragar, 1971), (b) $\mathrm{SiO}_{2}$ versus $\left(\mathrm{Na}_{2} \mathrm{O}+\mathrm{K}_{2} \mathrm{O}\right)$ total alkali-silica (TAS) diagram for volcanic rocks (after Le Bas et al., 1986), (c) $\mathrm{FeO}^{\mathrm{T}} /\left(\mathrm{MgO}+\mathrm{FeO}^{\mathrm{T}}\right)$ wt $\%$ versus $\mathrm{SiO}_{2}$ plot (after Frost et al., 2001), (d) $\mathrm{K}_{2} \mathrm{O}$ wt $\%$ versus $\mathrm{SiO}_{2} \mathrm{wt}^{2} \%$ plot (Peccerillo and Taylor, 1976).

Fig. 7. (a) $\left(\mathrm{Na}_{2} \mathrm{O}+\mathrm{K}_{2} \mathrm{O}\right) / \mathrm{CaO}$ versus $10^{4} \times \mathrm{Ga} / \mathrm{Al}$ and (b) $\mathrm{Zr}$ versus $10^{4} \times \mathrm{Ga} / \mathrm{Al}$ (after Whalen et al., 1987)

discriminating A-type granites from I, S type granites; (c) A/CNK [molar $\mathrm{Al}_{2} \mathrm{O}_{3} /\left(\mathrm{CaO} \times \mathrm{Na}_{2} \mathrm{O} \times\right.$ $\left.\mathrm{K}_{2} \mathrm{O}\right)$ ] versus $\mathrm{A} / \mathrm{NK}$ [molar $\left.\mathrm{Al}_{2} \mathrm{O}_{3} /\left(\mathrm{Na}_{2} \mathrm{O} \times \mathrm{K}_{2} \mathrm{O}\right)\right]$ diagram, the boundary line is from Maniar and Piccoli (1989); (d) Rb versus Th diagrams for the studied samples from the Khangay-Khentey basin.

Fig. 8. CI-chondrite-normalized REE patterns and primitive-mantle-normalized trace element spidergrams for the studied samples from the Khangay-Khentey basin. Both chondrite and primitive-mantle normalized values are from Sun and McDonough (1989). 
Fig. 9. (a) Correlations between whole-rock $\varepsilon_{\mathrm{Nd}}(t)$ and concordia ages. (b) Correlations between $\varepsilon_{\mathrm{Hf}}(t)$ and $\mathrm{Pb}-\mathrm{Pb}$ ages of zircons for the studied samples from the Khangay-Khentey basin.

Fig. 10. (a) $\mathrm{Nb} / \mathrm{Ta}$ versus $\mathrm{SiO}_{2}$ and (b) Er versus Dy diagrams showing hornblende fractionation for the Group III rock association from the Khangay-Khentey basin.

Fig. 11. (a) Plots of $\mathrm{La} / \mathrm{Yb}$ versus $\mathrm{La}$; (b) $\mathrm{Zr} / \mathrm{Nb}$ versus $\mathrm{Zr}$; (c) $\mathrm{Nb} / \mathrm{Zr}$ v versus $\mathrm{Th} / \mathrm{Zr}$; (d) $\mathrm{Rb} / \mathrm{Y}$ versus $\mathrm{Nb} / \mathrm{Y}$ for the Group I and III rock associations from the Khangay-Khentey basin.

Fig. 12. (a) Histogram shows zircon U-Pb age, two-stage crustal Hf, and Nd model ages; (b) Plots of whole-rock $\varepsilon_{\mathrm{Nd}}(t)$ versus zircon $\varepsilon_{\mathrm{Hf}}(t)$ of the studied samples from the Khangay-Khentey basin. The terrestrial array is from Vervoort et al. (1999).

Fig.13. Tectonic discrimination diagrams for the studied samples from the Khangay-Khentey basin in Central Mongolia: (a) Nb versus Y (Pearce et al., 1984); (b) $\mathrm{Th} / \mathrm{Yb}$ versus $\mathrm{Ta} / \mathrm{Yb}$ (Pearce et al., 2008). Syn-COLG-syn-collision granite; VAG-volcanic arc granite, WPG-within plate granite, Post-COLG-post-collisional granite; ACM-active continental margin; DM-depleted mantle; EMEnriched mantle.

Fig. 14. (a) $\mathrm{Ce} / \mathrm{Nb}$ versus $\mathrm{Y} / \mathrm{Nb}$ and (b) $3 \times \mathrm{Ga}-\mathrm{Nb}-\mathrm{Y}$ subdivision diagrams (after Eby, 1992) for A-type granites for the Group II rock association from the Khangay-Khentey basin. $A_{1}$-continental rift or intra-plate magmatism related granite; $\mathrm{A}_{2}-$ post-collisional setting or island-arc related granite. IAB-island arc basalt; OIB-oceanic island basalt.

Table 1. Mineral assemblage and contents of studied samples of the Khangay-Khentey basin.

Table 2. Summary of zircon characteristics of dated samples and corresponding ages.

Supplementary Table 1. Radiometric ages in the literature of the Late Paleozoic-Early Mesozoic granitoids in Central and Northeast Mongolia.

\section{Supplementary Table 2.}


LA-ICPMS U-Th-Pb analytical data for zircons of the studied samples from the Khangay-Khentey basin. * Discordant data excluded from calculation.

\section{Supplementary Table 3.}

Major (wt\%) and trace $(\mu \mathrm{g} / \mathrm{g})$ element compositions including sample location and rock type of the studied samples from the Khangay-Khentey basin.

Supplementary Table 4. Zircon Lu-Hf and whole-rock Sm-Nd isotope data of the studied samples from the Khangay-Khentey basin. 


\section{REFERENCES}

Amar-Amgalan, S., 2008. U-Pb geochronology and multi-isotopic systematics of granitoids from Mongolia, Central Asian Orogenic Belt: Implications for granitoid origin and crustal growth during the Phanerozoic. Unpublished Ph.D. thesis. Okayama University, Japan, p.162.

Aoki, S., Aoki, K., Tsujimori, T., Sakata, S., Tsuchiya, Y., 2020. Oceanic-arc subduction, stagnation, and exhumation: zircon U-Pb geochronology and trace-element geochemistry of the Sanbagawa eclogites in central Shikoku, SW Japan. Lithos, 358, 105378. https://doi.org/10.1016/j.lithos.2020.105378

Badarch, G., Cunningham, W.D., Windley, B.F., 2002. A new terrane subdivision for Mongolia: implications for the Phanerozoic crustal growth of Central Asia. Journal of Asian Earth Sciences, 21, 87-110. https://doi.org/10.1016/S1367-9120(02)00017-2

Black, L.P., Kamo, S.L., Allen, C.M., Aleinikoff, J.N., Davis, D.W., Korsch, R.J., Foudoulis, C., 2003. TEMORA 1: a new zircon standard for Phanerozoic U-Pb geochronology. Chemical geology, 200, 155-170. https://doi.org/10.1016/S0009-2541(03)00165-7

Bonin, B., 2007. A-type granites and related rocks: evolution of a concept, problems and prospects. Lithos, 97, 1-29. https://doi.org/10.1016/j.lithos.2006.12.007

Bouvier, A., Vervoort, J.D., Patchett, P.J., 2008. The Lu-Hf and Sm-Nd isotopic composition of CHUR: constraints from unequilibrated chondrites and implications for the bulk composition of terrestrial planets. Earth and Planetary Science Letters, 273, 48-57.

Bussien, D., Gombojav, N., Winkler, W., Von Quadt, A., 2011. The Mongol-Okhotsk Belt in Mongolia—an appraisal of the geodynamic development by the study of sandstone provenance and detrital zircons. Tectonophysics, 510, 132-150. https://doi.org/10.1016/j.tecto.2011.06.024

Chappell, B.W., Bryant, C.J., Wyborn, D., 2012. Peraluminous I-type granites. Lithos, 153, 142-153. https://doi.org/10.1016/j.lithos.2012.07.008

Chauvel, C., Marini, J.C., Plank, T., Ludden, J.N., 2009. Hf-Nd input flux in the Izu-Mariana subduction zone and recycling of subducted material in the mantle. Geochemistry, Geophysics, Geosystems, 10. https://doi.org/10.1029/2008GC002101

Chen, G.N., Grapes, R., 2007. Granite genesis: in-situ melting and crustal evolution, first ed. Springer. Dordrecht, Netherlands. 
Clemens, J.D., Stevens, G. and Bryan, S.E., 2020. Conditions during the formation of granitic magmas by crustal melting-hot or cold; drenched, damp or dry?. Earth-Science Reviews, 200, 102982.

Collins, W.J., Huang, H.Q., Bowden, P., Kemp, A.I.S., 2020. Repeated S-I-A-type granite trilogy in the Lachlan Orogen and geochemical contrasts with A-type granites in Nigeria: implications for petrogenesis and tectonic discrimination. Geological society, london, special publications, 491, 53-76. https://doi.org/10.1144/SP491-2018-159

Dagvadorj, D., Bold, G., Chuluun, D., Gundsambuu, Ts., 1993. Geological Map of the Central and Eastern Mongolia, Scale 1:500,000. Institute of Geological Research Regional Geological Sector, Ministry of Heavy industrial (in Mongolian).

Dagva-Ochir, L., Oyunchimeg, T.U., Enkhdalai, B., Safonova, I., Li, H., Otgonbaatar, D., Tamehe, L.S., Sharav, D., 2020. Middle Paleozoic intermediate-mafic rocks of the Tsoroidog Uul'accretionary complex, Central Mongolia: Petrogenesis and tectonic implications. Lithos, 376, 105795.

https://doi.org/10.1016/j.lithos.2020.105795

Dolzodmaa, B., Osanai, Y., Nakano, N., Adachi, T., 2020. Zircon U-Pb geochronology and geochemistry of granitic rocks in central Mongolia. Mongolian Geoscientist, 50, 23-44.

https://doi.org/10.5564/mgs.v50i0.1327

Donskaya, T.V., Gladkochub, D.P., Mazukabzov, A.M., Ivanov, A.V., 2013. Late Paleozoic-Mesozoic subduction-related magmatism at the southern margin of the Siberian continent and the 150 million-year history of the Mongol-Okhotsk Ocean. Journal of Asian Earth Sciences, 62, 79-97. https://doi.org/10.1016/j.jseaes.2012.07.023

Eby, G.N., 1992. Chemical subdivision of the A-type granitoids: petrogenetic and tectonic implications. Geology, 20, 641-644.

Ehiro, M., D Zakharov, Y.U., Minjni, C., 2006. Early Triassic (Olenekian) ammonoids from Khentey Province, Mongolia, and their paleobiogeographic significance. Bulletin of the Tohoku University Museum, 83-97.

Eroğlu, H., Kabadayi, Ö., 2013. Natural radioactivity levels in lake sediment samples. Radiation protection dosimetry, 156, 331-335.

Frost, B.R., Barnes, C.G., Collins, W.J., Arculus, R.J., Ellis, D.J., Frost, C.D., 2001. A geochemical classification for granitic rocks. Journal of Petrology, 42, 2033-2048. 
Goldstein, S.J., Jacobsen, S.B., 1988. Nd and Sr isotopic systematics of river water suspended material: implications for crustal evolution. Earth and Planetary Science Letters, 87, 249-265.

Irvine, T.N., Baragar, W.R.A., 1971. A guide to the chemical classification of the common volcanic rocks. Canadian Journal of Earth Sciences, 8, 523-548.

Izbrodin, I., Doroshkevich, A., Rampilov, M., Elbaev, A., Ripp, G., 2020. Late Paleozoic alkaline magmatism in Western Transbaikalia, Russia: Implications for magma sources and tectonic settings. Geoscience Frontiers, 11, 1289-1303. https://doi.org/10.1016/j.gsf.2019.12.009

Jacobsen, S.B., Wasserburg, G.J., 1984. Sm-Nd isotopic evolution of chondrites and achondrites, II. Earth and Planetary Science Letters, 67, 137-150. https://doi.org/10.1016/0012-821X(84)90109-2

Jahn, B.M., 2004. The Central Asian Orogenic Belt and growth of the continental crust in the Phanerozoic. Geological Society, London, Special Publications, 226, 73-100.

Jian, P., Kröner, A., Windley, B.F., Shi, Y., Zhang, W., Zhang, L. and Yang, W., 2012. Carboniferous and Cretaceous mafic-ultramafic massifs in Inner Mongolia (China): a SHRIMP zircon and geochemical study of the previously presumed integral "Hegenshan ophiolite". Lithos, 142, 48-66.

https://doi.org/10.1016/j.lithos.2012.03.007

Jochum, K.P., Weis, U., Stoll, B., Kuzmin, D., Yang, Q., Raczek, I., Jacob, D.E., Stracke, A., Birbaum, K., Frick, D.A., Günther, D., 2011. Determination of reference values for NIST SRM 610-617 glasses following ISO guidelines. Geostandards and Geoanalytical Research, 35, 397-429. https://doi.org/10.1111/j.1751908X.2011.00120.x

Jones, M.R., Soule, S.A., Gonnermann, H.M., Le Roux, V., Clague, D.A., 2018. Magma ascent and lava flow emplacement rates during the 2011 Axial Seamount eruption based on $\mathrm{CO}_{2}$ degassing. Earth and Planetary Science Letters, 494, 32-41. https://doi.org/10.1016/j.eps1.2018.04.044

Kemp, A.I.S., Hawkesworth, C.J., Paterson, B.A., Kinny, P.D., 2006. Episodic growth of the Gondwana supercontinent from hafnium and oxygen isotopes in zircon. Nature, 439, 580-583.

Kemp, A.I.S., Hawkesworth, C.J., Foster, G.L., Paterson, B.A., Woodhead, J.D., Hergt, J.M., Gray, C.M., Whitehouse, M.J., 2007. Magmatic and crustal differentiation history of granitic rocks from Hf-O isotopes in zircon. Science, 315, 980-983. 
Kröner, A., Kovach, V., Belousova, E., Hegner, E., Armstrong, R., Dolgopolova, A., Seltmann, R., Alexeiev, D.V., Hoffmann, J.E., Wong, J., Sun, M., 2014. Reassessment of continental growth during the accretionary history of the Central Asian Orogenic Belt. Gondwana Research, 25, 103-125.

https://doi.org/10.1016/j.gr.2012.12.023

Le Bas, M., Maitre, R.L., Streckeisen, A., Zanettin, B., 1986. A chemical classification of volcanic rocks based on the total alkali-silica diagram. Journal of Petrology, 27, 745-750.

Liu, H., Li, Y., He, H., Huangfu, P., Liu, Y., 2018. Two-phase southward subduction of the Mongol-Okhotsk oceanic plate constrained by Permian-Jurassic granitoids in the Erguna and Xing'an massifs (NE China). Lithos, 304, 347-361. https://doi.org/10.1016/j.lithos.2018.01.016

Macpherson, C.G., Dreher, S.T., Thirlwall, M.F., 2006. Adakites without slab melting: high pressure differentiation of island arc magma, Mindanao, the Philippines. Earth and Planetary Science Letters, 243, 581-593. https://doi.org/10.1016/j.eps1.2005.12.034

Maniar, P.D., Piccoli, P.M., 1989. Tectonic discrimination of granitoids. Geological society of America Bulletin, 101, 635-643.

Morozumi, H., 2003. Geochemical characteristics of granitoids of the Erdenet porphyry copper deposit, Mongolia. Resource Geology, 53, 311-316. https://doi.org/10.1111/j.1751-3928.2003.tb00180.x

Moyen, J.F., 2009. High Sr/Y and La/Yb ratios: the meaning of the "adakitic signature". Lithos, 112, 556574.

Munkhtsengel, B., Ohara, M., Gerel, O., Dandar, S., Tsuchiya, N., 2007. Preliminary Study of Formation Mechanism of the Erdenetiin Ovoo Porphyry Copper-Molybdenum Deposit and Environmental Effects of Erdenet Mine, Northern Mongolia. In AIP Conference Proceedings, 833, 204-207. American Institute of Physics. https://doi.org/10.1063/1.2207106

Nasdala, L., Hofmeister, W., Norberg, N., Martinson, J.M., Corfu, F., Dörr, W., Kamo, S.L., Kennedy, A.K., Kronz, A., Reiners, P.W. and Frei, D., 2008. Zircon M257-a homogeneous natural reference material for the ion microprobe $\mathrm{U}-\mathrm{Pb}$ analysis of zircon. Geostandards and Geoanalytical Research, 32, 247-265. https://doi.org/10.1111/j.1751-908X.2008.00914.x

Patchett, P.J., Tatsumoto, M., 1981. A routine high-precision method for Lu-Hf isotope geochemistry and chronology. Contributions to Mineralogy and Petrology, 75, 263-267. 
Patiño Douce, A.E., 1997. Generation of metaluminous A-type granites by low-pressure melting of calcalkaline granitoids. Geology, 25, 743-746.

Pearce, J.A., Harris, N.B. and Tindle, A.G., 1984. Trace element discrimination diagrams for the tectonic interpretation of granitic rocks. Journal of Petrology, 25, 956-983.

Pearce, J.A., Peate, D.W., 1995. Tectonic implications of the composition of volcanic arc magmas. Annual Review of Earth and Planetary Sciences, 23, 251-286.

Pearce, J.A., 2008. Geochemical fingerprinting of oceanic basalts with applications to ophiolite classification and the search for Archean oceanic crust. Lithos, 100, 14-48.

Peccerillo, A., Taylor, S.R., 1976. Geochemistry of Eocene calc-alkaline volcanic rocks from the Kastamonu area, northern Turkey. Contributions to Mineralogy and Petrology, 58, 63-81.

Rubatto, D., Hermann, J., 2003. Zircon formation during fluid circulation in eclogites (Monviso, Western Alps): implications for $\mathrm{Zr}$ and $\mathrm{Hf}$ budget in subduction zones. Geochimica et Cosmochimica acta, 67, 21732187.

Rudnick, R.L., Gao, S., 2003. Composition of the continental crust., in Gao, S., Holland, H.D., Turekian, K.K., The Crust, 3, Elsevier, Amsterdam, Netherlands. pp. 1-64

Safonova, I., Seltmann, R., Kröner, A., Gladkochub, D., Schulmann, K., Xiao, W., Kim, J., Komiya, T., Sun, M., 2011. A new concept of continental construction in the Central Asian Orogenic Belt. Episodes, 34, 186196.

Safonova, I., Kotlyarov, A., Krivonogov, S., Xiao, W., 2017. Intra-oceanic arcs of the Paleo-Asian Ocean. Gondwana Research, 50, 167-194.

Safonova, I., 2017. Juvenile versus recycled crust in the Central Asian Orogenic Belt: Implications from ocean plate stratigraphy, blueschist belts and intra-oceanic arcs. Gondwana Research, 47, 6-27.

Schmitz, M.D., Vervoort, J.D., Bowring, S.A., Patchett, P.J., 2004. Decoupling of the Lu-Hf and Sm-Nd isotope systems during the evolution of granulitic lower crust beneath southern Africa. Geology, 32, 405408. https://doi.org/10.1130/G20241.1

Sláma, J., Košler, J., Condon, D.J., Crowley, J.L., Gerdes, A., Hanchar, J.M., Horstwood, M.S., Morris, G.A., Nasdala, L., Norberg, N., Schaltegger, U., 2008. Plešovice zircon-a new natural reference material for 
$\mathrm{U}-\mathrm{Pb}$ and $\mathrm{Hf}$ isotopic microanalysis. Chemical Geology, 249, 1-35.

https://doi.org/10.1016/j.chemgeo.2007.11.005

Söderlund, U., Patchett, P.J., Vervoort, J.D., Isachsen, C.E., 2004. The 176Lu decay constant determined by $\mathrm{Lu}-\mathrm{Hf}$ and $\mathrm{U}-\mathrm{Pb}$ isotope systematics of Precambrian mafic intrusions. Earth and Planetary Science Letters, 219, 311-324. https://doi.org/10.1016/S0012-821X(04)00012-3

Sorokin, A.A., Zaika, V.A., Kovach, V.P., Kotov, A.B., Xu, W., Yang, H., 2020. Timing of closure of the eastern Mongol-Okhotsk Ocean: Constraints from $\mathrm{U}-\mathrm{Pb}$ and $\mathrm{Hf}$ isotopic data of detrital zircons from metasediments along the Dzhagdy Transect. Gondwana Research, 81, 58-78.

https://doi.org/10.1016/j.gr.2019.11.009

Sun, S.S., McDonough, W.F., 1989. Chemical and isotopic systematics of oceanic basalts: implications for mantle composition and processes. Geological Society, London, Special Publications, 42, 313-345. https://doi.org/10.1144/GSL.SP.1989.042.01.19

Sun, D.Y., Gou, J., Wang, T.H., Ren, Y.S., Liu, Y.J., Guo, H.Y., Liu, X.M., Hu, Z.C., 2013.

Geochronological and geochemical constraints on the Erguna massif basement, NE China-subduction history of the Mongol-Okhotsk oceanic crust. International Geology Review, 55, 1801-1816.

Taylor, S.R., McLennan, S.M., 1995. The geochemical evolution of the continental crust. Reviews of geophysics, 33, 241-265.

Tiepolo, M., Vannucci, R., 2014. The contribution of amphibole from deep arc crust to the silicate Earth's Nb budget. Lithos, 208, 16-20. https://doi.org/10.1016/j.lithos.2014.07.028

Tomurtogoo, O., Windley, B.F., Kröner, A., Badarch, G., Liu, D.Y., 2005. Zircon age and occurrence of the Adaatsag ophiolite and Muron shear zone, central Mongolia: constraints on the evolution of the MongolOkhotsk ocean, suture and orogen. Journal of the Geological Society, 162, 125-134.

https://doi.org/10.1144/0016-764903-146

Tumurchudur, D., Bold, G., Chuluun, D., Gundsambuu, Ts., 2006. Geological Map of the Ikh-Khorgo area, Scale 1:50,000. Gurvantalst LLC, Mongolia (in Mongolian)

Turner, S.P., Foden, J.D., Morrison, R.S., 1992. Derivation of some A-type magmas by fractionation of basaltic magma: an example from the Padthaway Ridge, South Australia. Lithos, 28, 151-179. https://doi.org/10.1016/0024-4937(92)90029-X 
Vermeesch, P., 2018. IsoplotR: A free and open toolbox for geochronology. Geoscience Frontiers, 9(5), 1479-1493. https://doi.org/10.1016/j.gsf.2018.04.001

Vervoort, J.D., Patchett, P.J., Blichert-Toft, J., Albarède, F., 1999. Relationships between Lu-Hf and Sm-Nd isotopic systems in the global sedimentary system. Earth and Planetary Science Letters, 168, 79-99.

Whalen, J.B., Currie, K.L., Chappell, B.W., 1987. A-type granites: geochemical characteristics, discrimination and petrogenesis. Contributions to mineralogy and petrology, 95, 407-419.

Wiedenbeck, M., Hanchar, J.M., Peck, W.H., Sylvester, P., Valley, J., Whitehouse, M., Kronz, A., Morishita, Y., Nasdala, L., Fiebig, J., Franchi, I., 2004. Further characterisation of the 91500 zircon crystal. Geostandards and Geoanalytical Research, 28, 9-39.

Wilhem, C., Windley, B.F., Stampfli, G.M., 2012. The Altaids of Central Asia: a tectonic and evolutionary innovative review. Earth-Science Reviews, 113, 303-341. https://doi.org/10.1016/j.earscirev.2012.04.001

Windley, B.F., Alexeiev, D., Xiao, W., Kröner, A., Badarch, G., 2007. Tectonic models for accretion of the Central Asian Orogenic Belt. Journal of the Geological Society, 164, 31-47. https://doi.org/10.1144/001676492006-022

Wu, F.Y., Yang, Y.H., Xie, L.W., Yang, J.H., Xu, P., 2006. Hf isotopic compositions of the standard zircons and baddeleyites used in U-Pb geochronology. Chemical Geology, 234, 105-126.

https://doi.org/10.1016/j.chemgeo.2006.05.003

Xiao, W., Huang, B., Han, C., Sun, S., Li, J., 2010. A review of the western part of the Altaids: a key to understanding the architecture of accretionary orogens. Gondwana Research, 18, 253-273.

Yarmolyuk, V.V., Kovalenko, V.I., Sal'nikova, E.B., Budnikov, S.V., Kovach, V.P., Kotov, A.B., Ponomarchuk, V.A., 2002. Tectono-magmatic zoning, magma sources, and geodynamics of the Early Mesozoic Mongolia-Transbaikal province. Geotectonics, 36, 293-311.

Yarmolyuk, V.V., Kuzmin, M.I., Ernst, R.E., 2014. Intraplate geodynamics and magmatism in the evolution of the Central Asian Orogenic Belt. Journal of Asian Earth Sciences, 93, 158-179.

https://doi.org/10.1016/j.jseaes.2014.07.004

Yi, Z., Meert, J.G., 2020. A closure of the Mongol-Okhotsk Ocean by the Middle Jurassic: Reconciliation of paleomagnetic and geological evidence. Geophysical Research Letters, 47, https://doi.org/10.1029/2020GL088235 
Zhao, P., Xu, B., Jahn, B.M., 2017. The Mongol-Okhotsk Ocean subduction-related Permian peraluminous granites in northeastern Mongolia: Constraints from zircon $\mathrm{U}-\mathrm{Pb}$ ages, whole-rock elemental and $\mathrm{Sr}-\mathrm{Nd}-\mathrm{Hf}$ isotopic compositions. Journal of Asian Earth Sciences, 144, 225-242. https://doi.org/10.1016/j.jseaes.2017.03.022

973

Zhu, M., Zhang, F., Miao, L., Baatar, M., Anaad, C., Yang, S., Li, X., 2016. Geochronology and geochemistry of the Triassic bimodal volcanic rocks and coeval A-type granites of the Olzit area, Middle Mongolia: Implications for the tectonic evolution of Mongol-Okhotsk Ocean. Journal of Asian Earth Sciences, 122, 41-57. https://doi.org/10.1016/j.jseaes.2016.03.001 
Figure 1

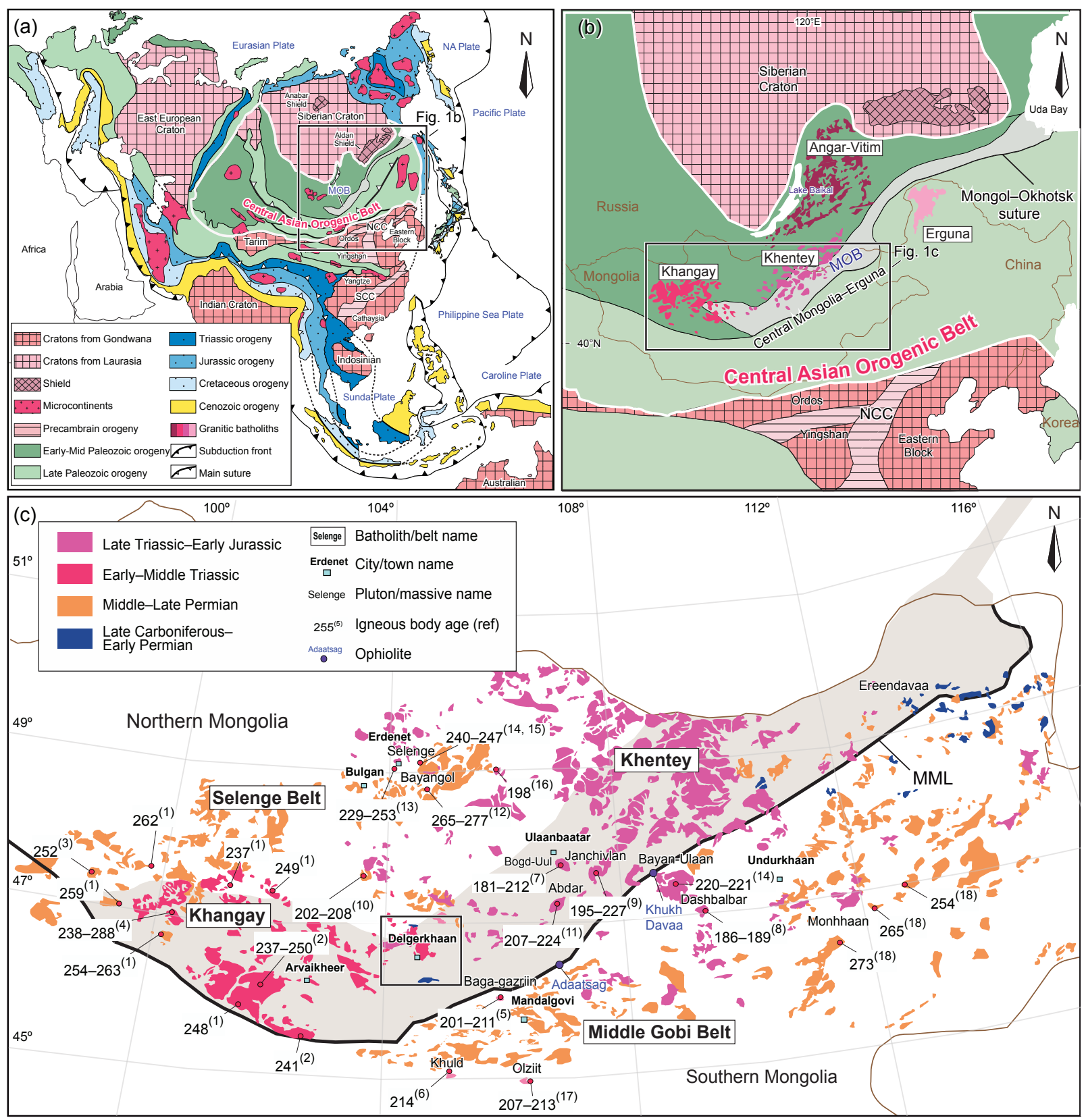


Figure 2

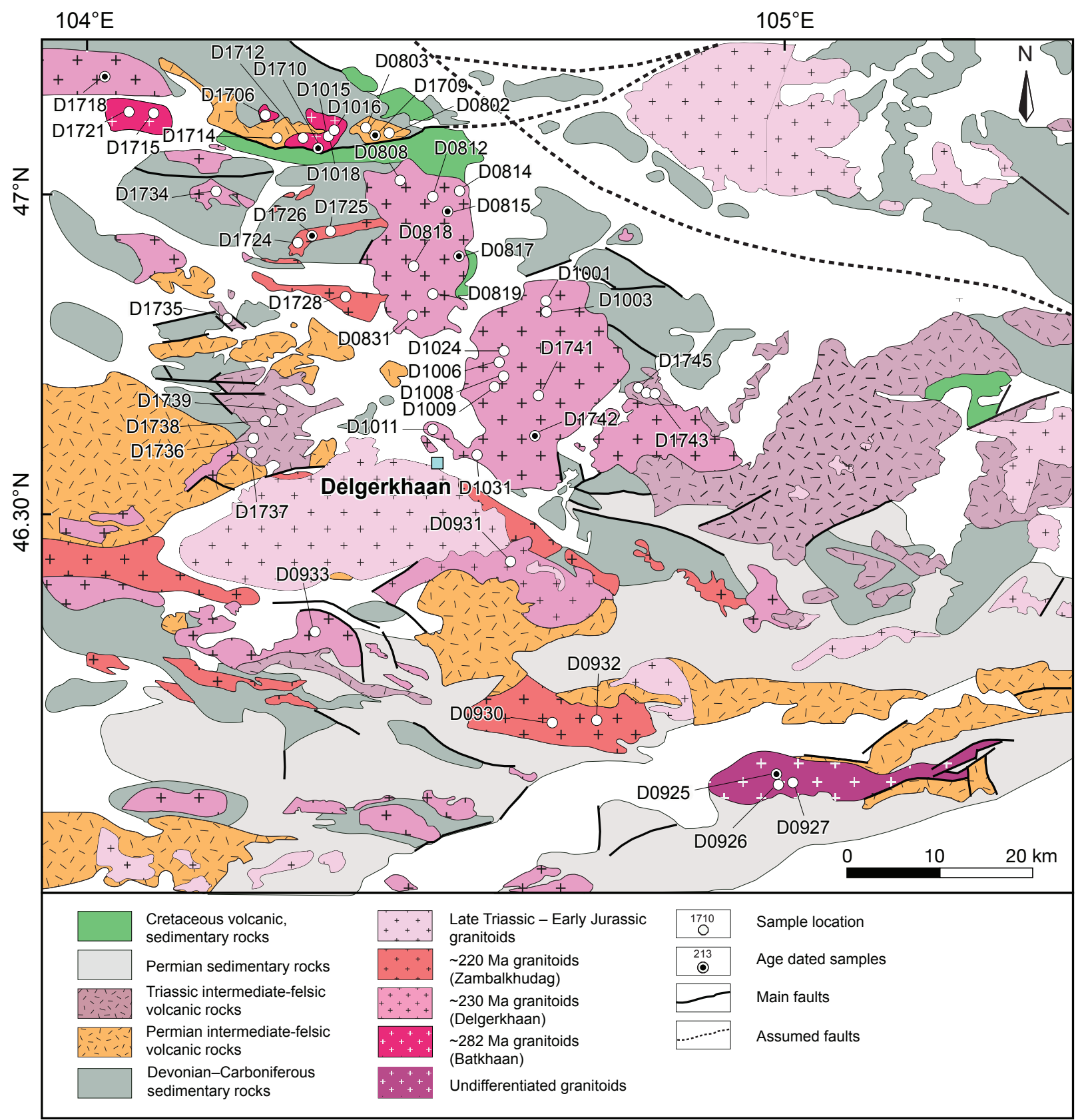


Figure 3
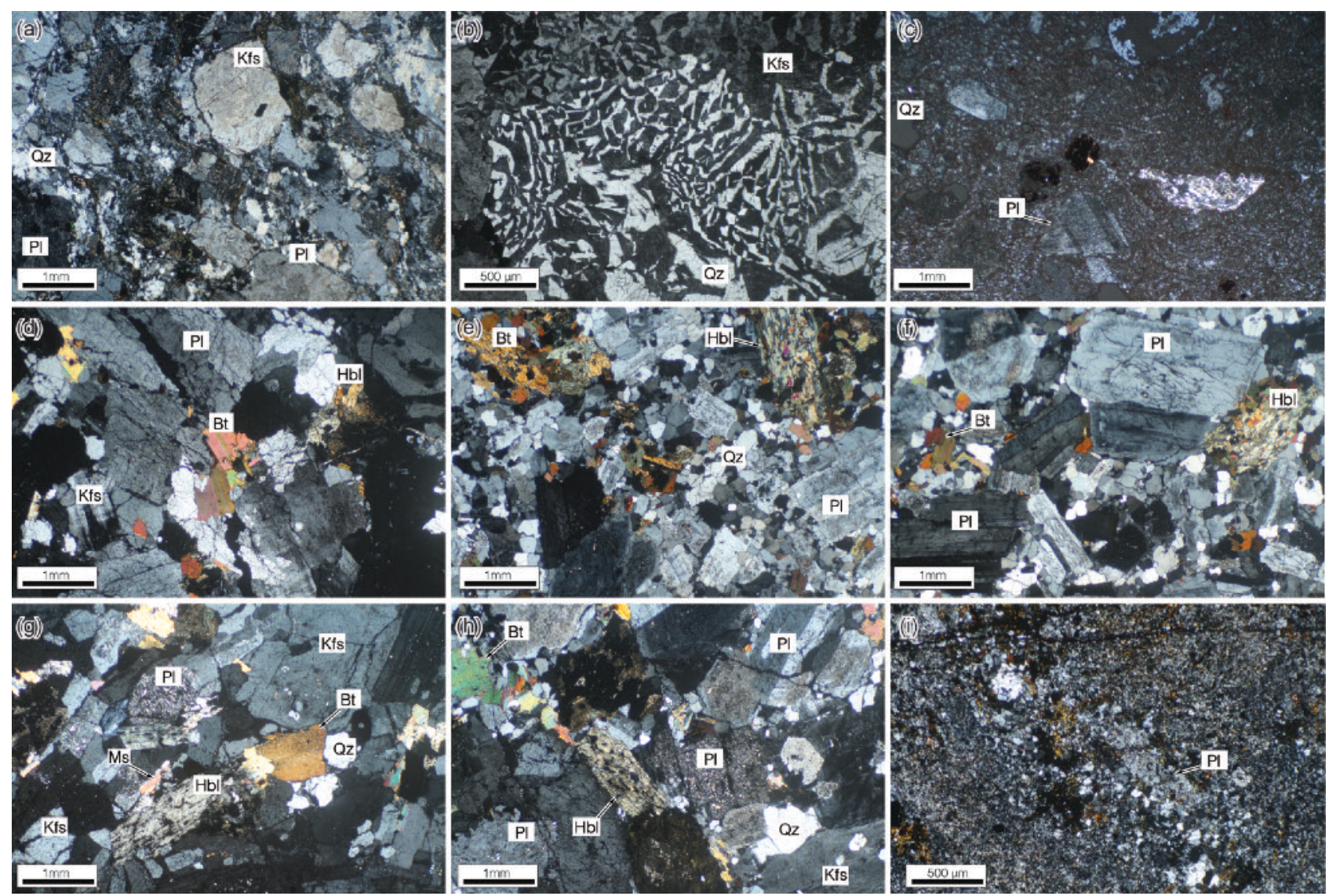
Figure 4
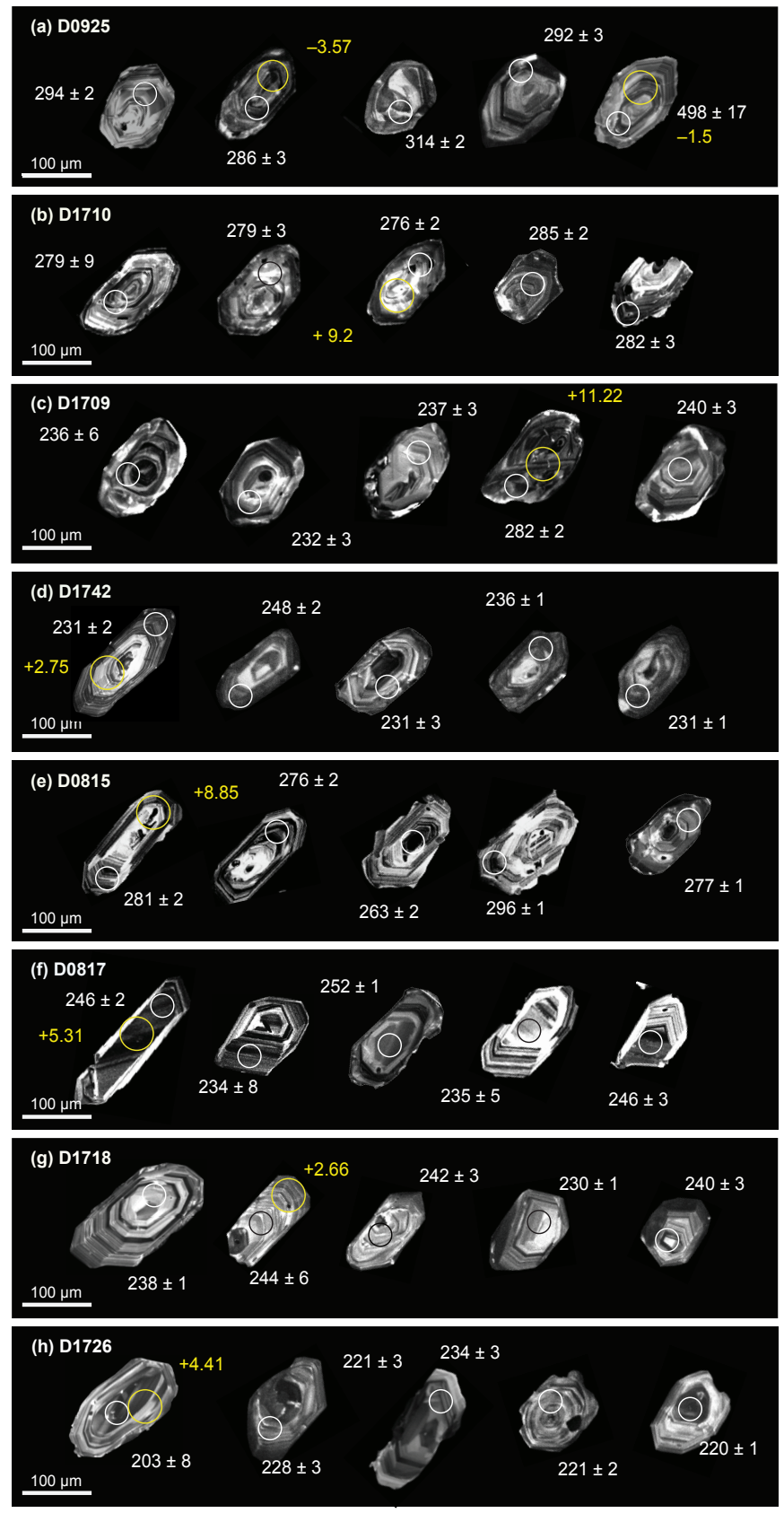


\section{Figure 5}
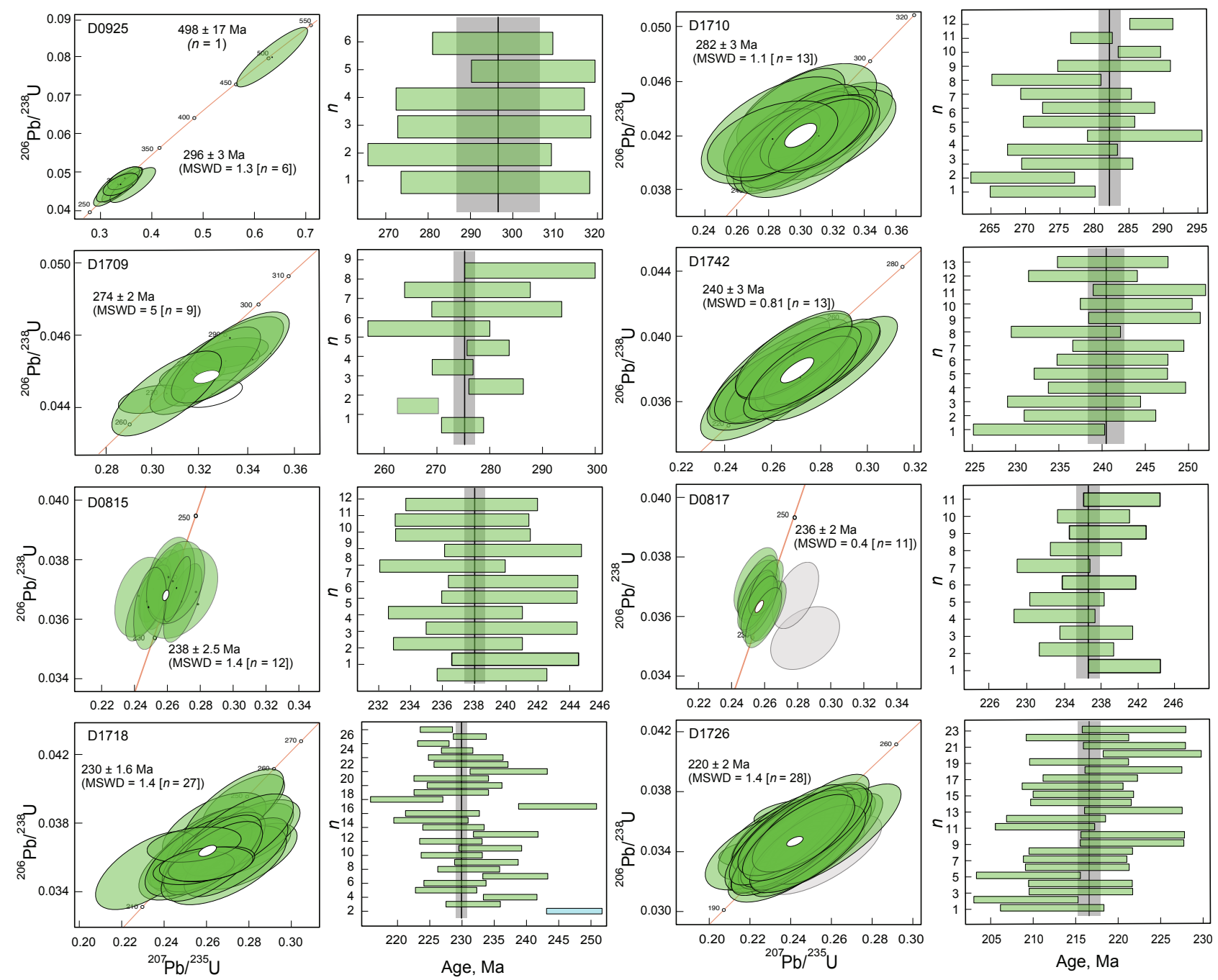
Figure 6
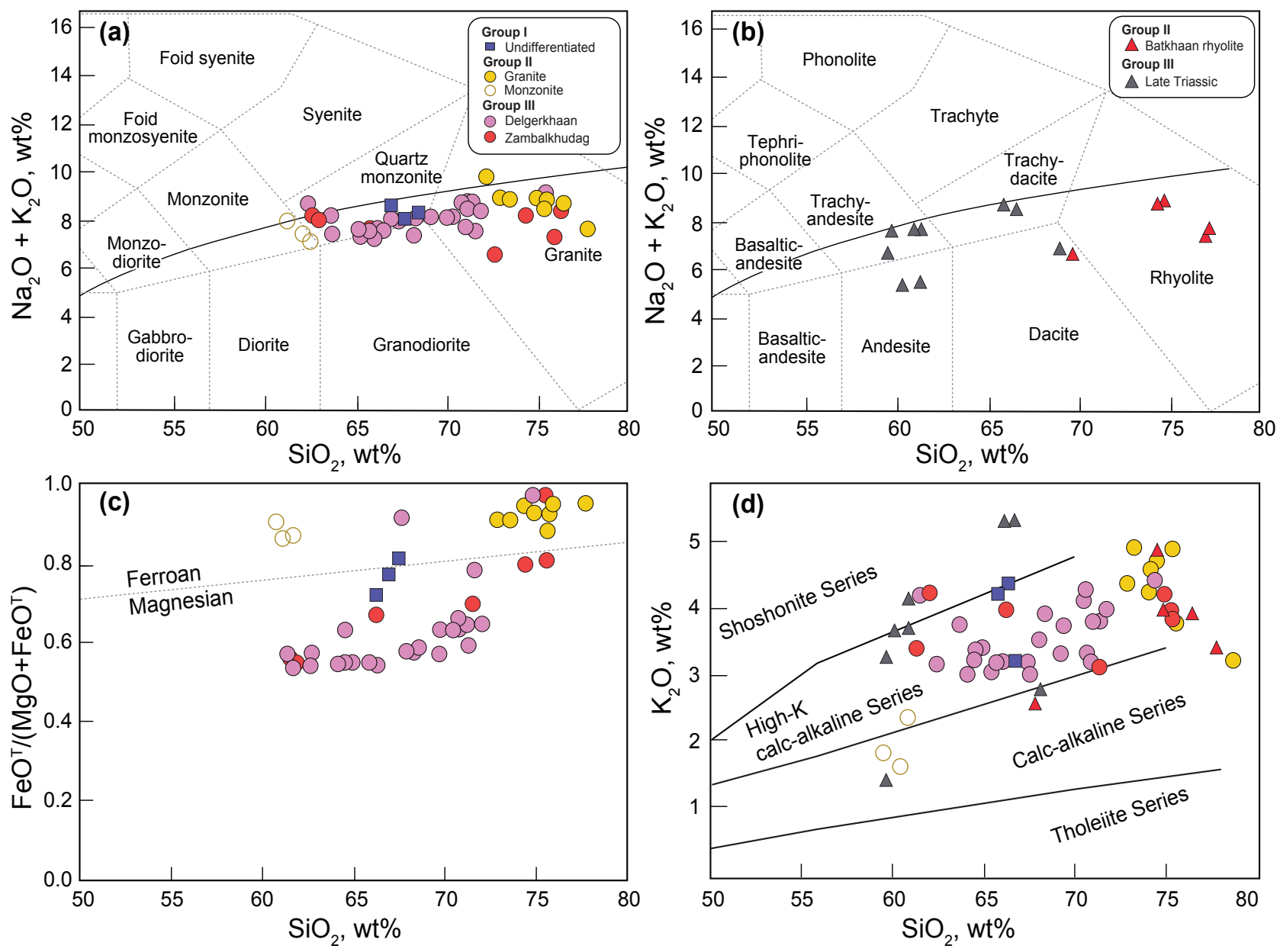
Figure 7
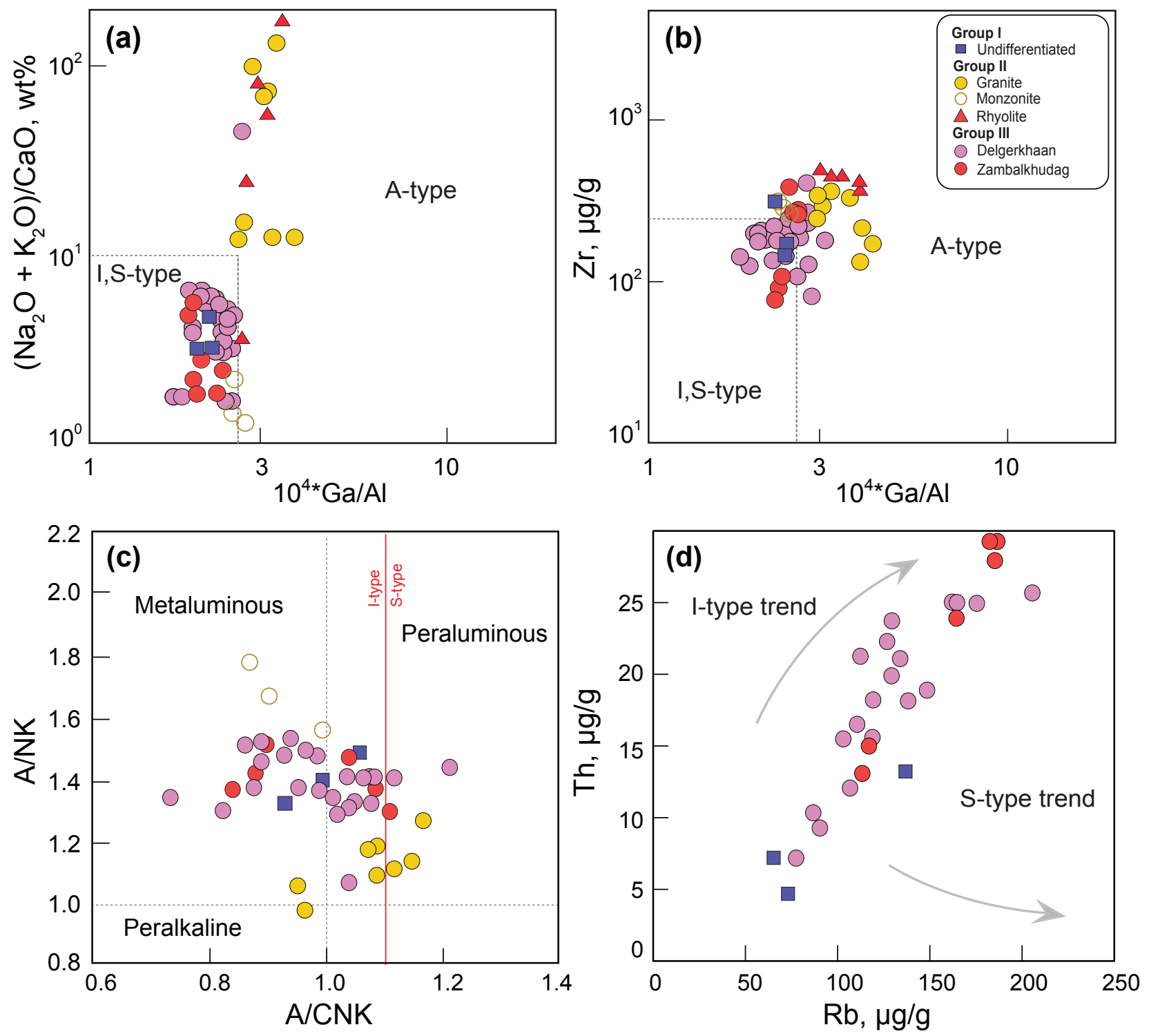
Figure 8
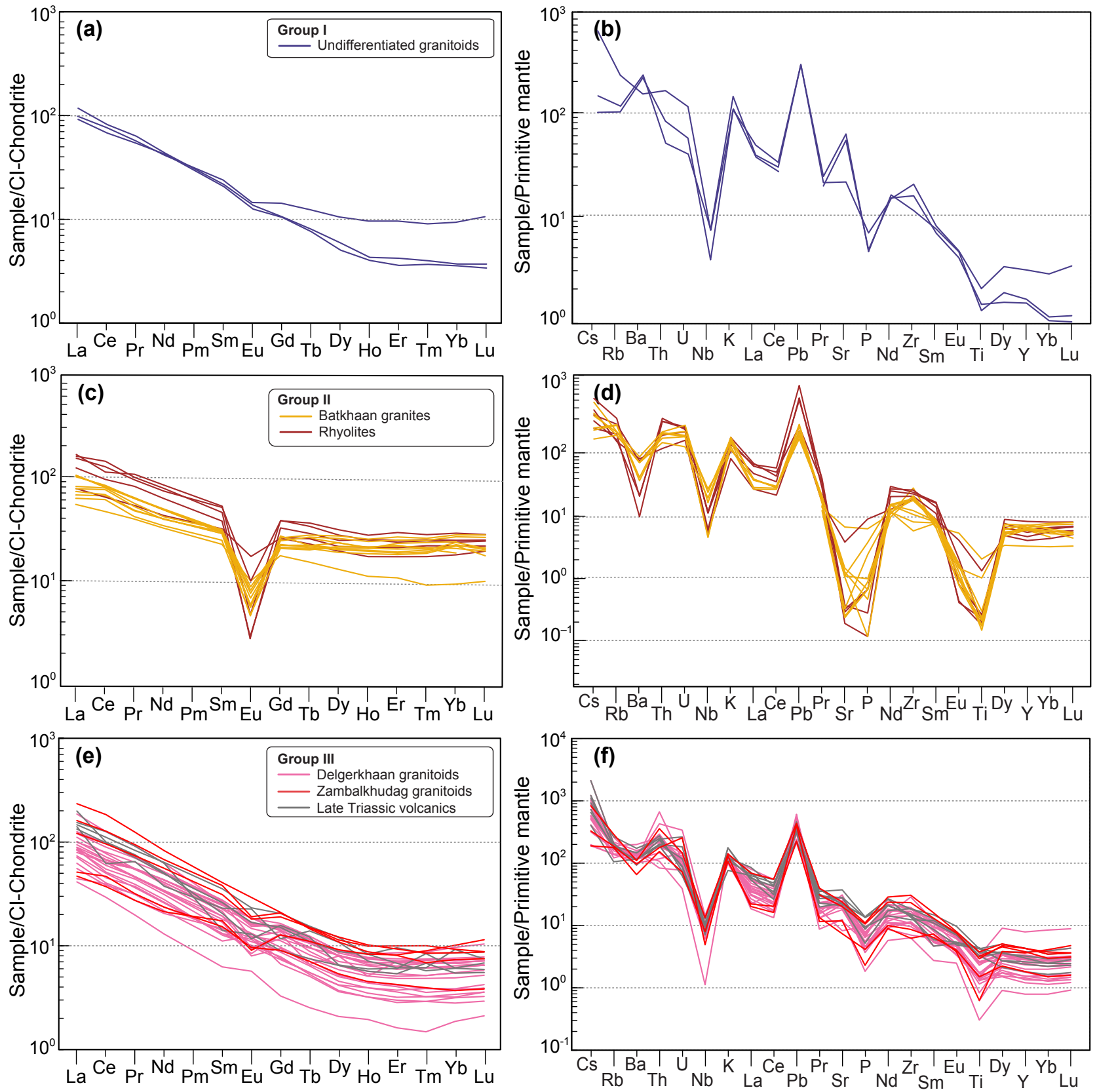
Figure 9
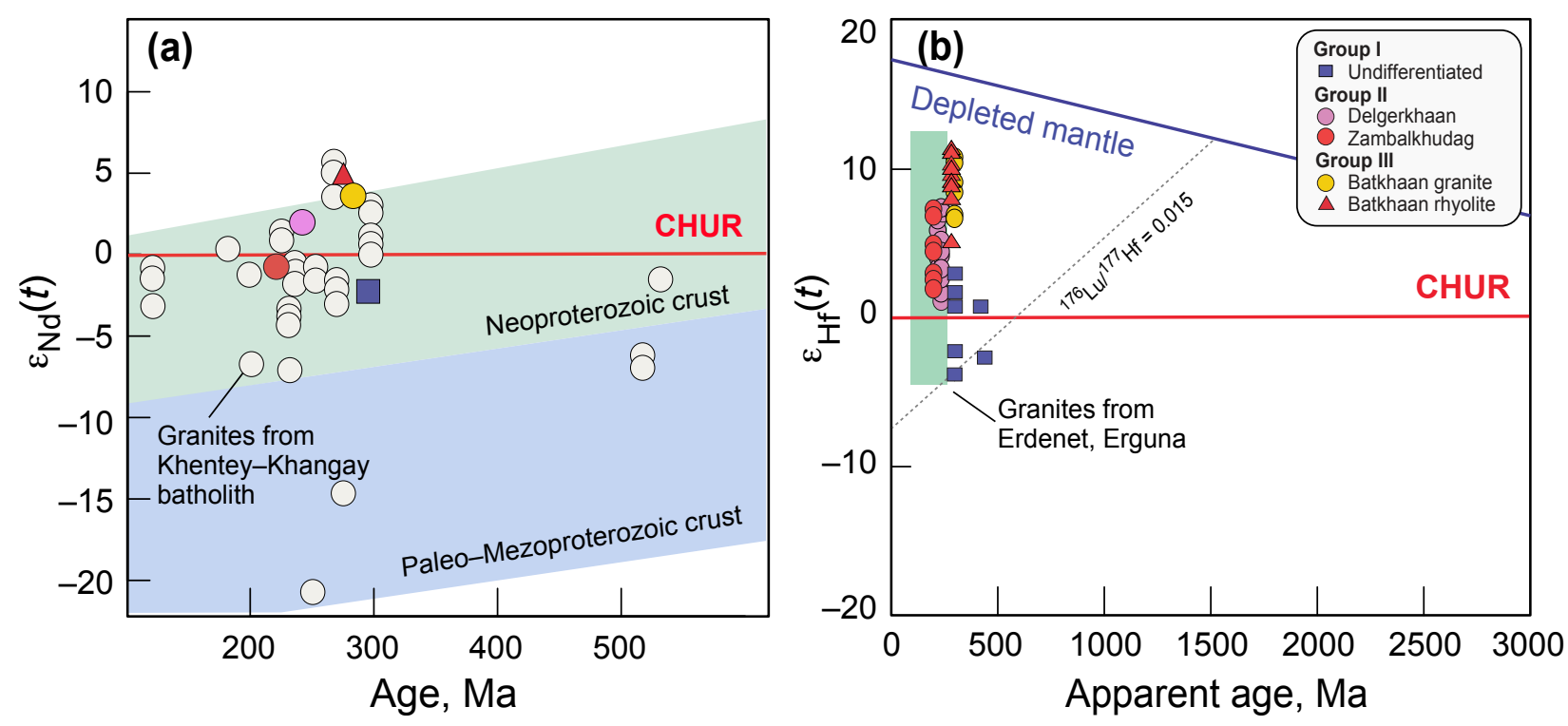
Figure 10
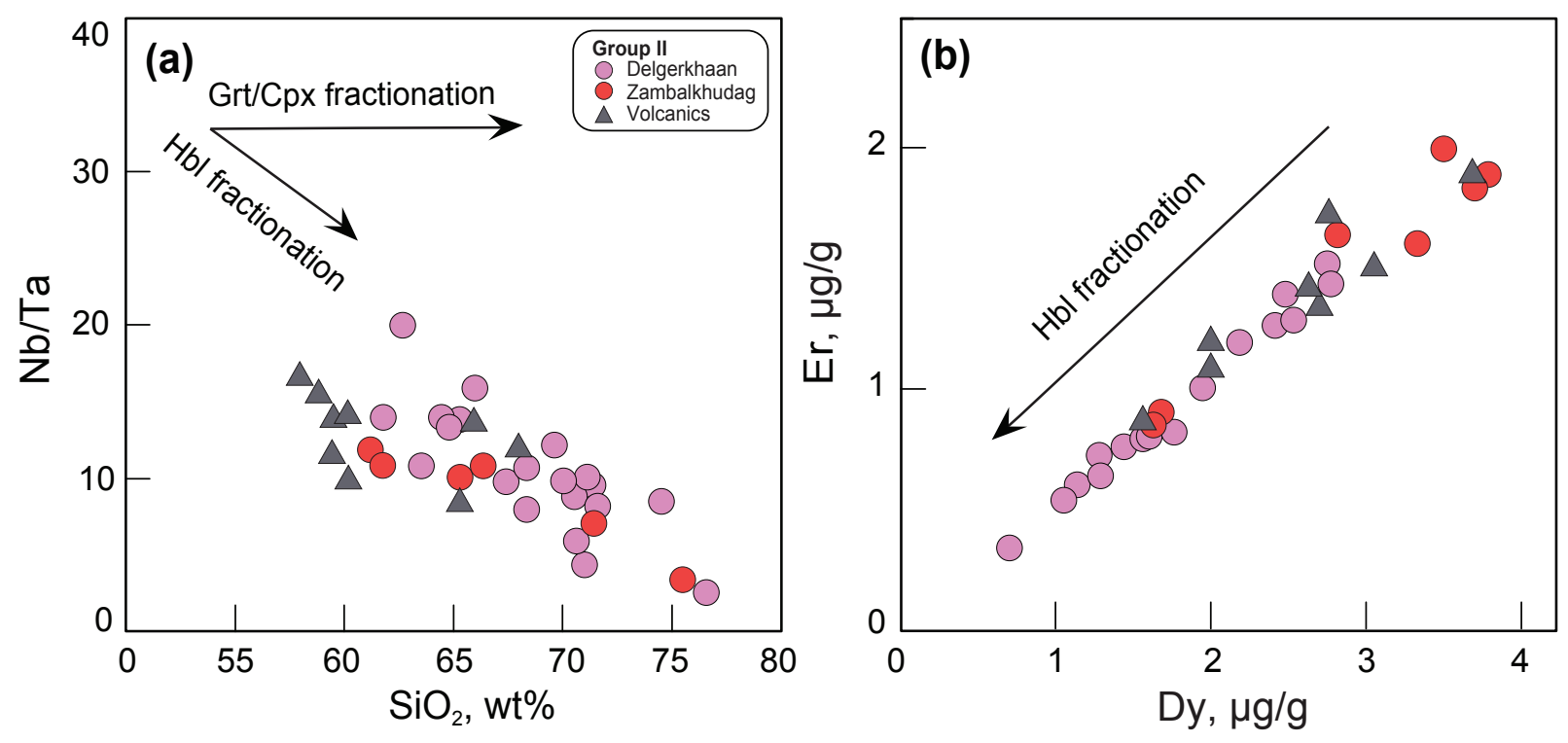
Figure 11
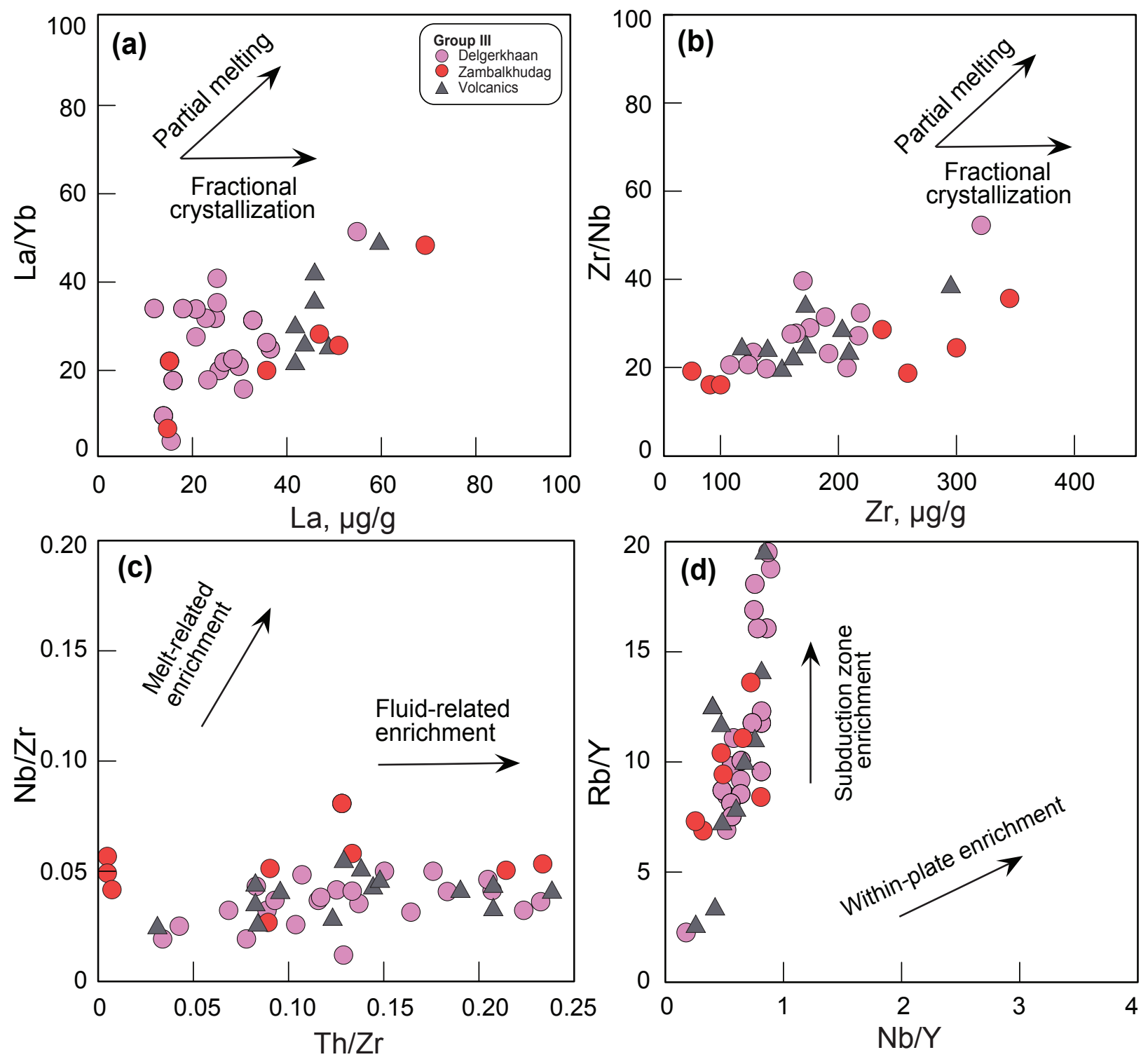
Figure 12
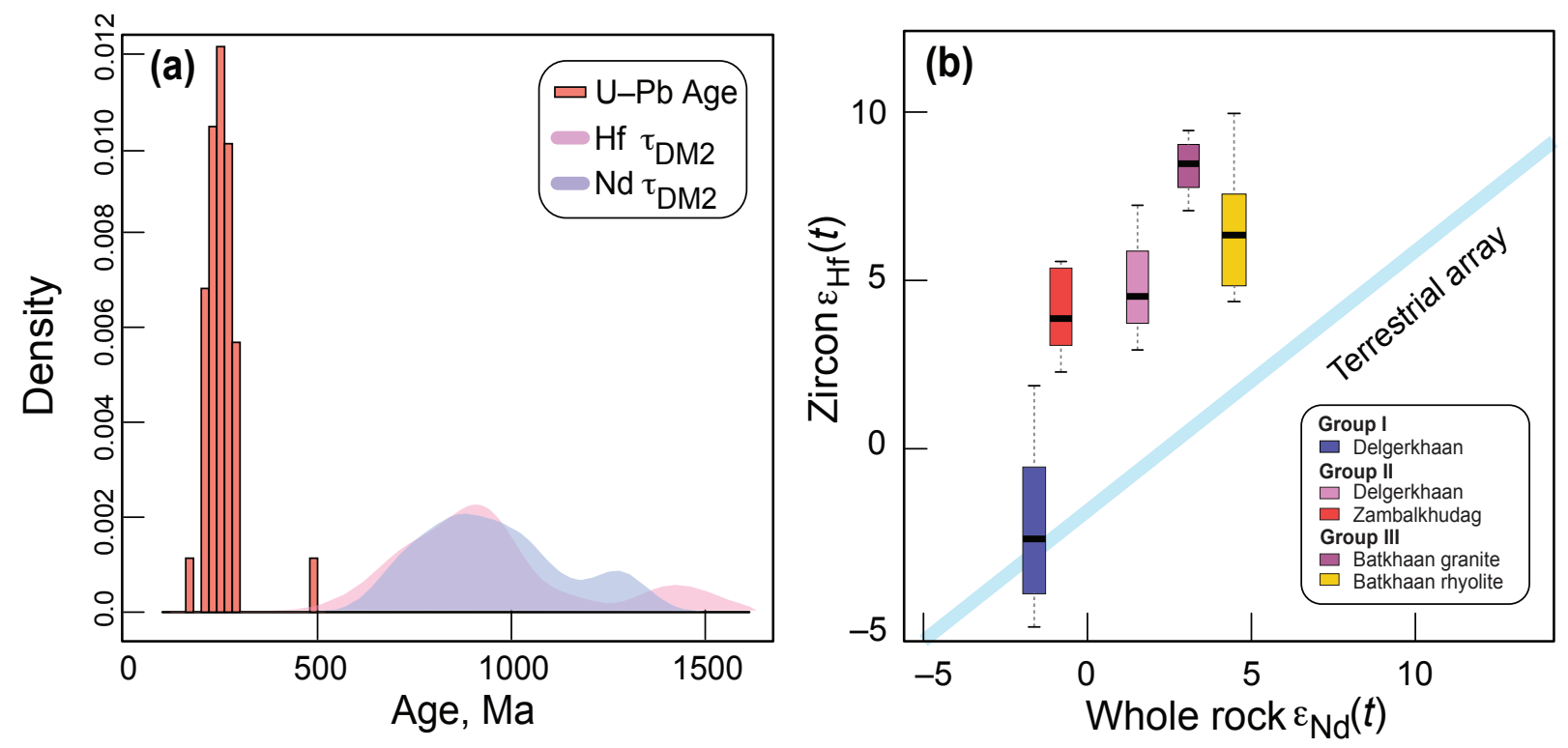
Figure 13
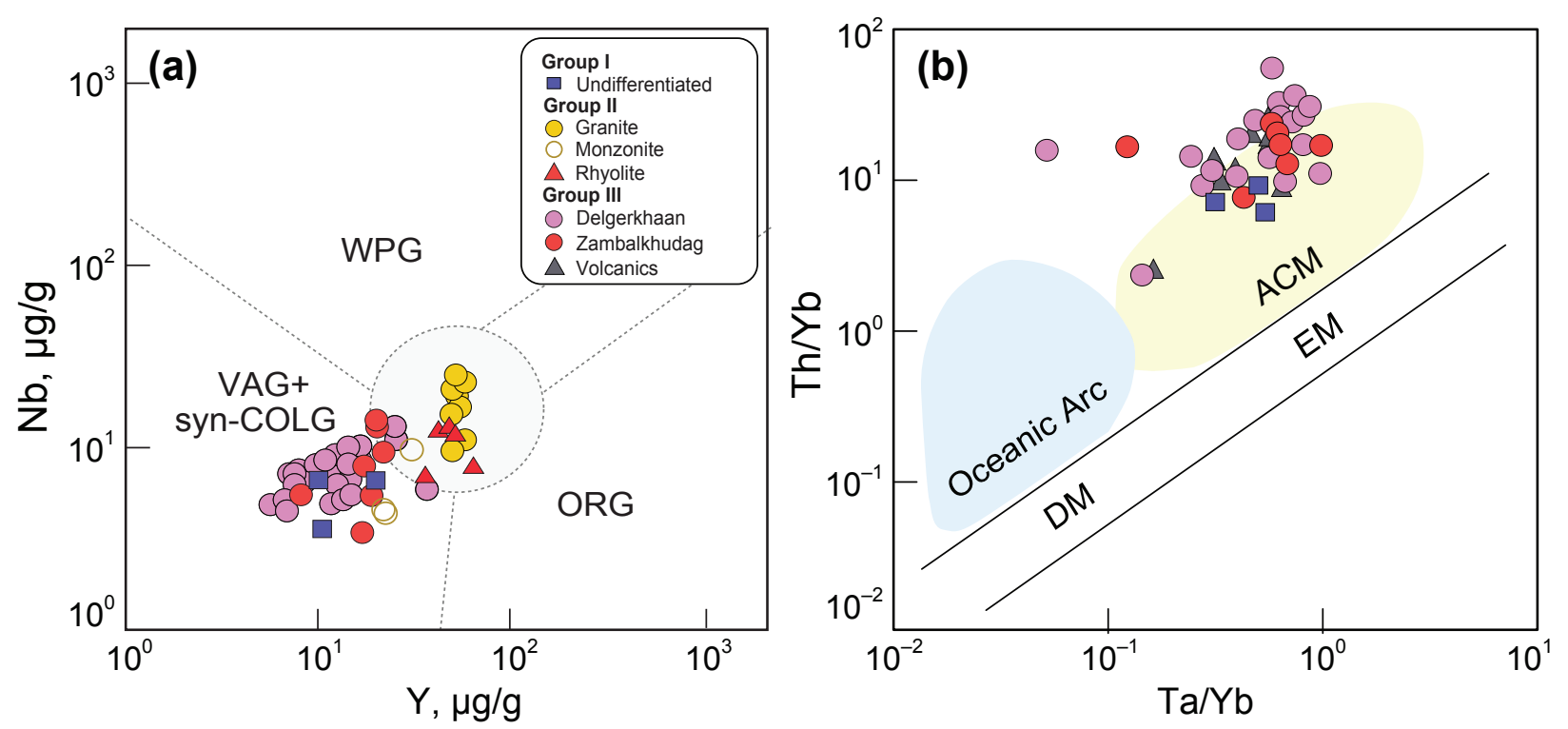
Figure 14
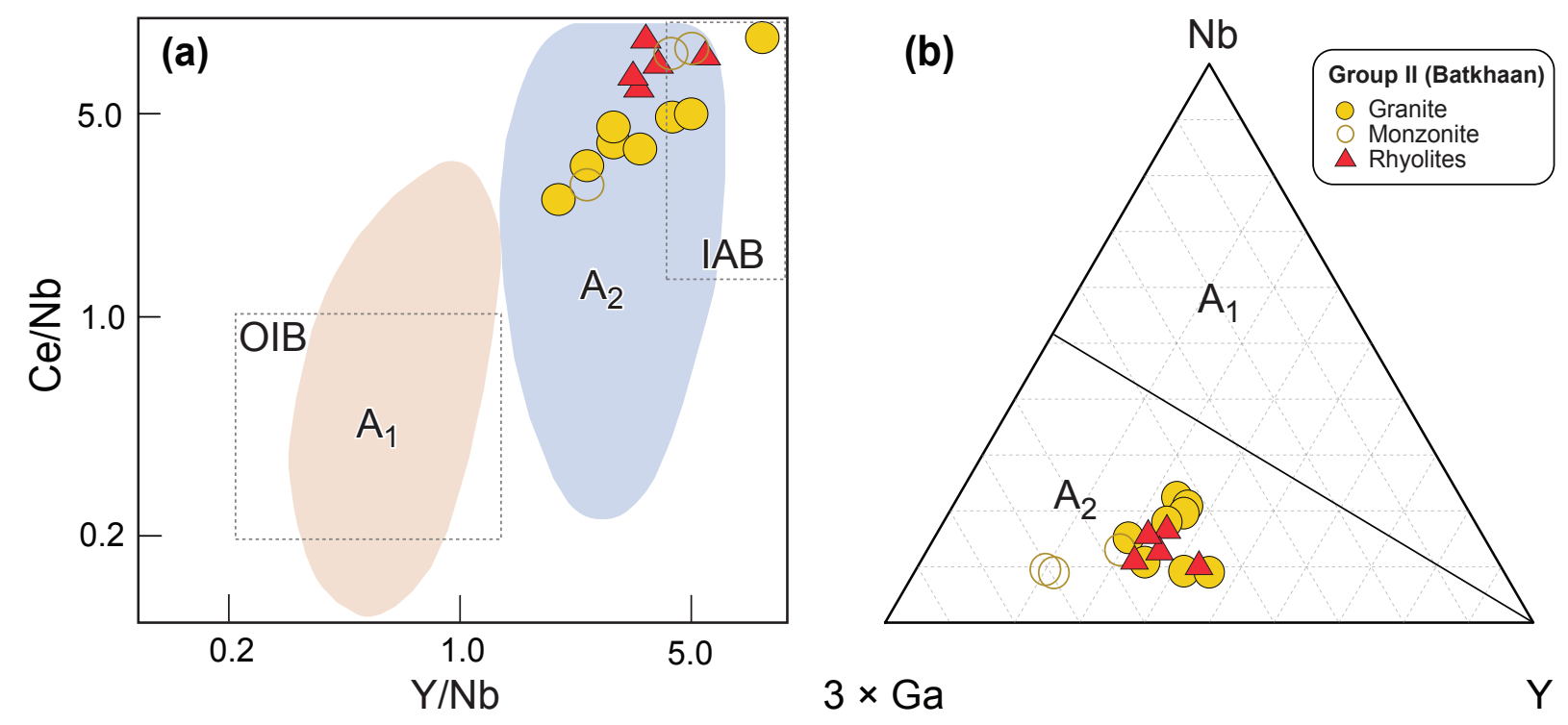